\title{
Sedimentology and sequence stratigraphy of a Tithonian-Valanginian carbonate ramp (Vaca Muerta Formation): A misunderstood exceptional source rock in the Southern Mendoza area of the Neuquén Basin, Argentina
}

\author{
Diego A. Kietzmann ${ }^{\mathrm{a}, \mathrm{c}}, *$, Ricardo M. Palma ${ }^{\mathrm{a}, \mathrm{c}}, \mathrm{A} 1 \mathrm{~b}$ e r t o C. R i c c a r d i ${ }^{\mathrm{b}, \mathrm{c}}$, \\ Javier Martín-Chivelet $^{\text {d,e }}$, José López-Gómez ${ }^{\text {d,e }}$
}

a b s t r a c t

The Vaca Muerta Formation (early Tithonian-early Valanginian) is a rhythmic succession of marls and lime-stones, cropping out in the Neuquén Basin, west-central Argentina. This lithostratigraphic unit was traditionally interpreted as basinal to slope deposits. Detailed facies analysis allows to differentiate seven facies associations, representing basinal to middle ramp facies of a homoclinal ramp system prograding westward from the eastern margin, and slope facies attributed to a distally steepened ramp system that progrades eastward from the Andean volcanic arc in the west. Two sequence hierarchies are recognized: five third order depositional sequences, and fifteen fourth order high-frequency sequences. Fluctuations in organic matter content within the Vaca Muerta Formation suggest relationship with depositional sequences, finding the highest values associated with transgressive system tracts. This work represents an important advance in the understanding of the sedimentary and stratigraphic evolution of this exceptional unconventional reservoir. Our sequence stratigraphic approach contributes to the understanding of the relationship between organic matter, facies, and sea-level changes.

\section{Keywords:}

Carbonate ramp, Source rock, Shale-gas systems, Depositional sequences, Jurassic -Cretaceous boundary

1. Introduction

The Vaca Muerta Formation consists of dark bituminous shales, marls and limestones deposited as a result of a rapid and widespread Palaeopacific early Tithonian to early Valanginian marine transgression in the Neuquén Basin, west-central Argentina (Legarreta and Uliana, 1991, 1996). This lithostratigraphic unit is widely distributed over an area of $120,000 \mathrm{~km}^{2}$ (Leanza et al., 1977; Uliana et al., 1977), and is considered to be the most effective source interval in the Neuquén Basin (Mitchum and Uliana, 1985; Uliana and Legarreta, 1993; Cruz et al., 2002). Actually, more than $75 \%$ of discovered hydrocarbons in

* Corresponding author at: Instituto de Estudios Andinos Don Pablo Groeber, Departamento de Ciencias Geológicas, Facultad de Ciencias Exactas y Naturales, Universidad de Buenos Aires, Ciudad Autónoma de Buenos Aires, Argentina. Tel./fax: +54

1145763329.

E-mail addresses: diegokietzmann@gl.fcen.uba.ar (D.A. Kietzmann), palma@gl.fcen.uba.ar (R.M. Palma), riccardi@fcnym.unlp.edu.ar (A.C. Riccardi), j.m.chivelet@geo.ucm.es (J. Martín-Chivelet), jlopez@geo.ucm.es (J. López-Gómez).
Argentina were generated in this Late Jurassic-Early Cretaceous source rock (Uliana et al., 1999). Remaining reserves and production data asso-ciated with petroleum systems indicate that about $50 \%$ of hydrocarbons comes from the Vaca Muerta Formation, which shows a prevalence of oil over gas (Legarreta et al., 2005).

The Vaca Muerta Formation has some of the best characteristics for shalegas/oil systems, with high average total organic carbon (TOC) levels (N4.0\%), moderate depth $(\sim 2400 \mathrm{~m})$ and overpressured condi-tions (Boyer et al., 2011; Giusiano et al., 2011).

Previous works on the Vaca Muerta Formation are relevant to this study, particularly those which cover palaeontological aspects and sed-imentological interpretations of economic importance for hydrocarbon exploration. Early regional stratigraphical studies were conducted by Weaver (1931), Groeber (1946, 1953), Marchese (1971), Leanza (1973), Leanza et al. (1977), Gulisano et al. (1984), Mitchum and Uliana (1985), a n d Legarreta and Gulisano (1989), who interpreted the Vaca Muerta Formation as basin and slope facies.

Sedimentological studies were carried out mostly in the south of the basin (Neuquén sector) by Spalletti et al. (2000), Scasso et al. (2005), 
and Kietzmann and Vennari (2013), whereas in the north (Mendoza sector) important advances have been made by Kietzmann (2011), Kietzmann and Palma (2011), a n d Kietzmann et al. (2008, 2011a).

The Upper Jurassic-Lower Cretaceous sequence stratigraphic framework has been based on seismic data (Gulisano et al., 1984; Mitchum and Uliana, 1985; Legarreta and Gulisano, 1989; Legarreta and Uliana, 1991), and calibrated with the global chart of third-order eustatic sealevel variations by Legarreta and Uliana $(1991,1996)$.

The aim of this study is to improve the understanding of the paleoenvironmental evolution of the Vaca Muerta Formation succession integrating sedimentological outcrop information of nine localities, south of Mendoza province (Fig. 1), an area of special relevance for this type of unconventional gas reservoirs. Based on detailed outcrop data we propose a new sequence stratigraphic scheme, which is com-pared with previous schemes based on seismic data and outcrop infor-mation. Also we attempt understand the relationship between organic matter, facies, and sea-level changes.

\section{Geological setting}

\subsection{The Neuquén Basin}

The Neuquén Basin was a retro-arc basin developed in Mesozoic times in the Pacific margin of S outh A merica (Legarreta and Uliana, 1991, 1996). Its stratigraphy was defined by Groeber $(1946,1953)$ and Stipanicic (1969), who recognized three sedimentary cycles, i.e. Jurásico, Ándico and Riográndico. This scheme was updated by Legarreta and Gulisano (1989), who emphasized the importance of eustatic changes in the devel-opment of depositional sequences (Fig. 2).

Different tectonic regimes (Legarreta and Uliana, 1991, 1996) e x e r t e d a first-order control in basin development and sedimentary evolution. An extensional regime was established during Late Triassic-Early Jurassic, and was characterized by a series of narrow, isolated depocenters con-trolled by large transcurrent fault systems filled mainly with continental deposits of the Precuyo Group (Manceda and Figueroa, 1993; Vergani et al., 1995; Giambiagi et al., 2008).

Thermal subsidence with localized tectonic events characterized the Early Jurassic to Late Cretaceous interval (Vergani et al., 1995). Depocenters were filled by continental and marine siliciclastic, carbon-ate and evaporitic sediments (Cuyo, Lotena, and Mendoza Groups).

Marine sequences developed throughout the basin during Late Jurassic-Early Cretaceous, are included in the Mendoza Group (Stipanicic, 1969) or Mendoza Mesosequence (Legarreta and Gulisano, 1989) (Fig. 2). Legarreta and Gulisano (1989) divided the Mendoza Mesosequence into three main shallowing-upward sedimentary cycles: Lower Mendoza Mesosequence (lower Tithonian-lower Valanginian), Middle Mendoza Mesosequence (lower Valanginian), and Upper Mendoza Mesosequence (lower Valanginian-lower Barremian).

A compressive deformation regime was established during the Late Cretaceous, and continued throughout the Cenozoic, although alternating with extensional events (Ramos and Folguera, 2005; Ramos, 2010). This Andean deformation resulted in the development of a series of $\mathrm{N}-\mathrm{S}$-oriented fold and thrust belts (Aconcagua, Marlargüe and Agrio fold and thrust belts) where excellent outcrops of the Mesozoic successions are exposed (e.g. Giambiagi et al., 2003; Ramos and Folguera, 2005; Ramos, 2010).

\subsection{The Lower Mendoza Mesosequence}

The Lower Mendoza Mesosequence includes a Tithonian-Valanginian broad shallowing-upward sedimentary cycle (Fig. 2), in which most distal
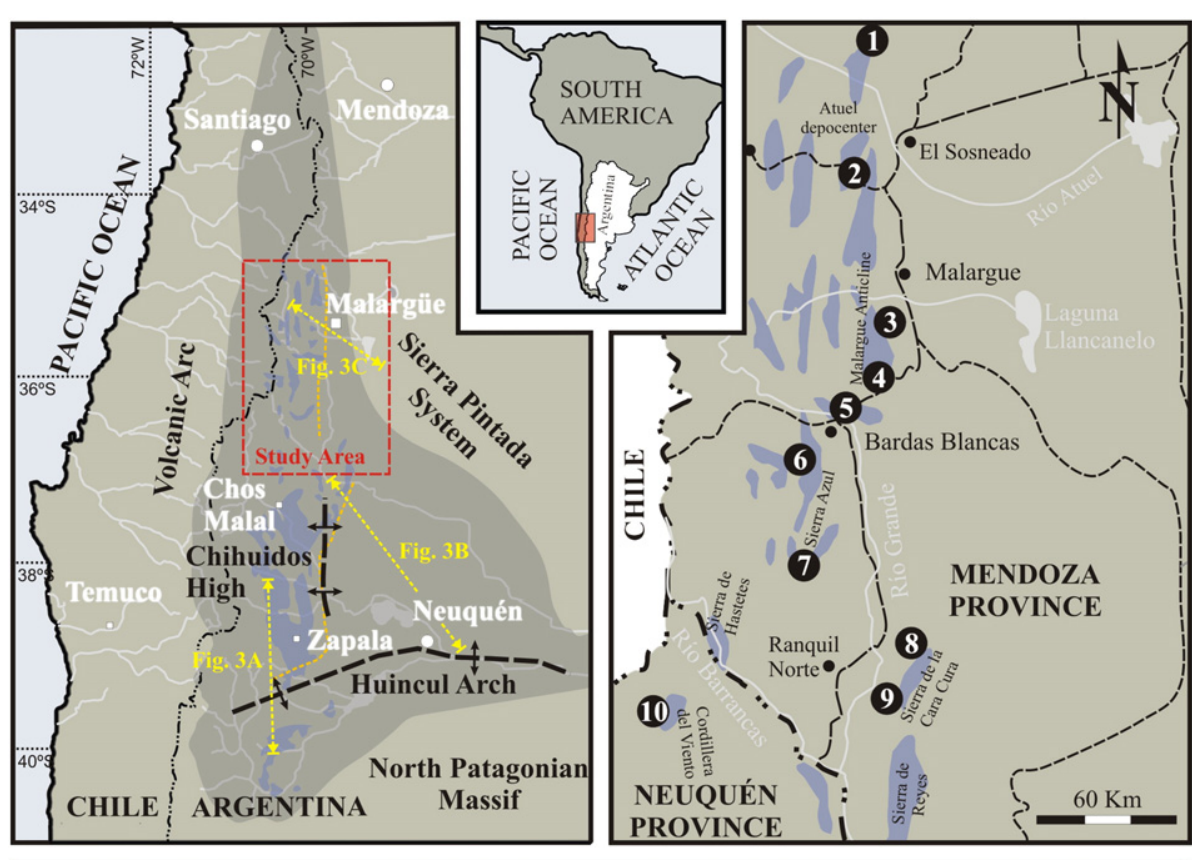

\section{References}
Neuquén Basin
(1) Arroyo La Manga
6 Arroyo Rahue
Mendoza Group
2 Cañada Ancha
Fluvial courses
(3) Arroyo Loncoche
-- Principal routes
(4) Cuesta del Chihuido
$(7)$ Mallín Redondo
Fold and thrust belt (FTB)
(5) Bardas Blancas
8 North Cara Cura
(9) South Cara Cura
(11) Cerro Domuyo

Fig. 1. Location map of the Neuquén Basin showing main geological features and studied localities. 

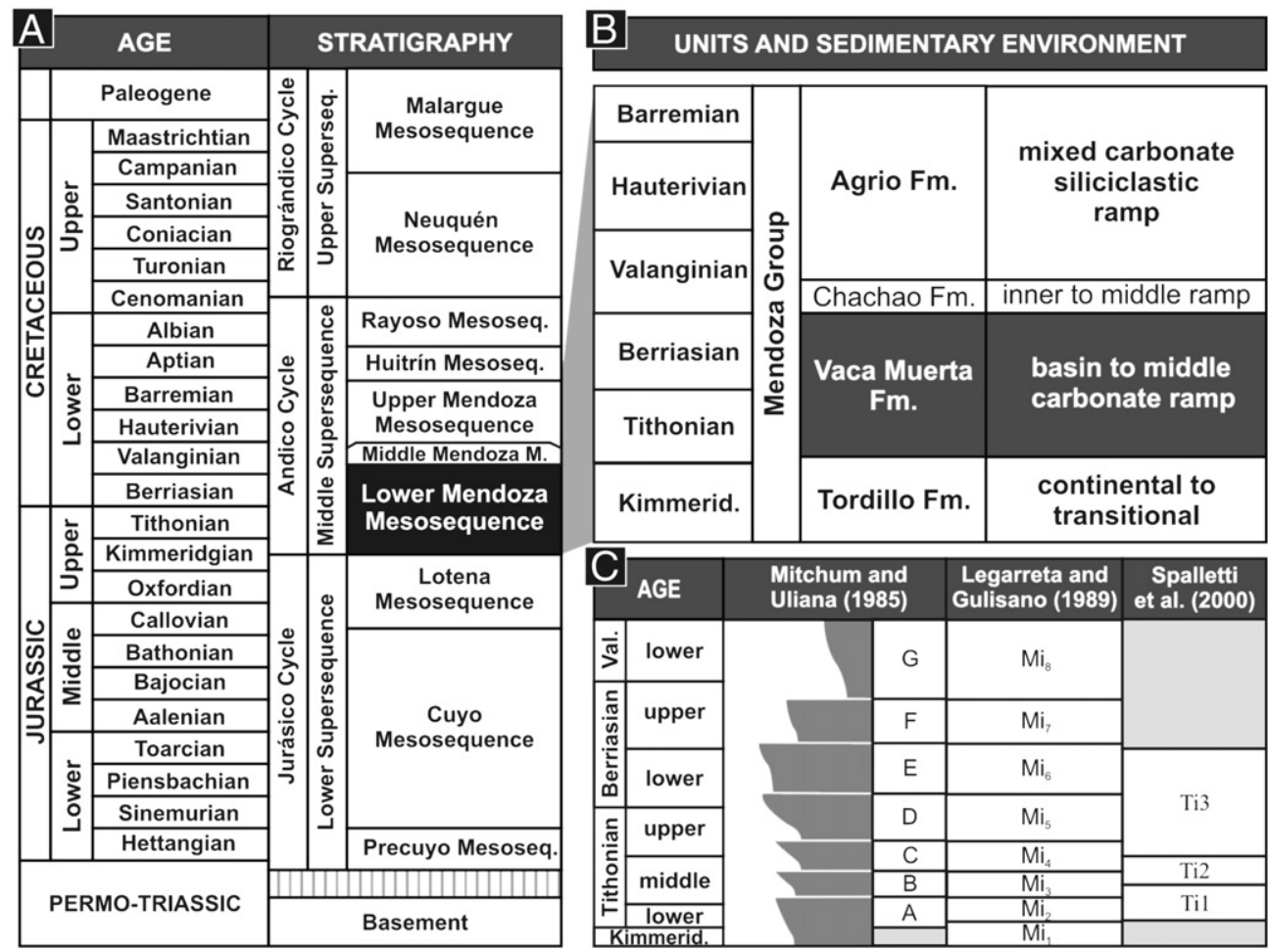

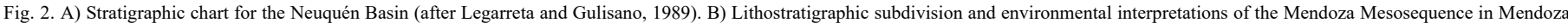

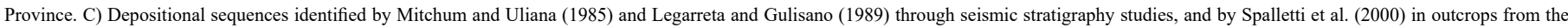
south of the Neuquén Basin

facies are included into the Vaca Muerta Formation. This interval was studied with some detail in the southern sector of the basin (Neuquén Province), where it was divided into nine depositional sequences $\left(\mathrm{Mi}_{1}-\mathrm{Mi}_{9}\right)$. The Lower Mendoza Mesosequence shows a general sigmoi-dal geometry, and thickness reaching $2000 \mathrm{~m}$ (Gulisano et al., 1984; Mitchum and Uliana, 1985; Legarreta and Gulisano, 1989; Legarreta and Uliana, 1991) ( Fig. 3).

In the southern part of the Neuquén Basin the Lower Mendoza Mesosequence includes the basinal deposits of the Vaca Muerta Forma-tion (early to middle Tithonian), which to the south-southeast change to mixed carbonate-siliciclastic nearshore deposits of the Carrin Cura Formation (lower part of the middle Tithonian) and Picún Leufú Forma-tion (middle Tithonianlower Berriasian), and to continental deposits of the Bajada Colorada Formation of Tithonian-Berriasian age (Leanza, 1973; Spalletti et al., 2000; Leanza et al., 2011) ( Fig. 3A).

In the central part of the Neuquén Basin, also known as Neuquén embayment due to the morphology of the paleocoast (Fig. 1), the Lower Mendoza Mesosequence consists of basinal deposits of the Vaca Muerta Formation (early to upper Tithonian), which to the east change to shoreface deposits of the Quintuco Formation (upper Tithonian-lower Valanginian), and to sabkha deposits of the Loma Montosa For-mation (lower Valanginian), forming a mixed carbonate-siliciclastic depositional system (Gulisano et al., 1984; Mitchum and Uliana, 1985; Carozzi et al., 1993) ( Fig. 3B). Westward the Vaca Muerta Formation in-cludes slope facies (Huncal Member), and in the Chilean territory pass into shallow marine/volcanic deposits (Charrier, 1985; Leanza et al., 2011; Kietzmann and Vennari, 2013).

In contrast, in the southern Mendoza area the Lower Mendoza Mesosequence consists of divergent sequences, with a maximum thick-ness of $500 \mathrm{~m}$ towards the center of the basin (Legarreta and Gulisano, 1989). It includes basinal to middle carbonate ramp deposits of the Vaca Muerta Formation (early Tithonian-early Valanginian) and middle to inner ramp oyster-deposits of the Chachao Formation (early Valanginian)(Fig. 2), which form a homoclinal carbonate ramp system (e.g. Carozzi et al., 1981; Mitchum and Uliana, 1985). Westward undated tidal to continental mixed deposits have been recognized and correlated with the Vaca Muerta and Chachao Formations, receiving the name of Lindero de Piedra Formation (Legarreta et al., 1981) ( Fig. 3C).

In the Mendoza area the Chachao Formation received much more at-tention than the Vaca Muerta Formation. Detailed descriptions can be found in Mombru et al. (1978), Carozzi et al. (1981), Legarreta and Kozlowski (1981), Palma and Angeleri (1992), Palma (1996), Palma and Lanés (2001), a n d Palma et al. (2008). New data are provided here for a better understanding of the relationship between both units, and their sedimentary environments.

Sedimentary differences between the southernmost Neuquén area, the Neuquén embayment and the Mendoza area are related to varia-tions in siliciclastic input due to latitudinal position (Volkheimer et al., 2008) and tectonic reactivation of large Late Triassic-Early Jurassic halfgrabens (Marchese, 1971; Orchuela et al., 1981). Two large struc-tures were active during Late Jurassic-Early Cretaceous times, generat-ing several unconformities in the sedimentary record, and particularly the "intravalanginian uncorformity" between the Vaca Muerta and Mulichinco Formations (Vergani et al., 1995). One structure is known as Huincul High (Fig. 1), an outstanding E-W morpho-structural feature that divides the Neuquén Basin into two, and reaches its present config-uration during this period. The other large structure developed parallel to the Andean axis is known as Chihuidos High (Maretto and Pángaro, 2005).

\section{Age and temporal framework}

Upper Jurassic-Lower Cretaceous biostratigraphy in the Neuquén $\mathrm{B}$ a s i n i s w e $11 \mathrm{~d}$ e fined on the basis of ammonites (cf. Aguirre-Urreta et al., 2011; Riccardi, 2008; Riccardi et al., 2000, 2011), and to a lesser extent on bivalves, brachiopods, and microfossils, such as foraminifers, calcareous nannofossils, radiolarians and dinoflagellates (Quattrocchio et al., 1996; Bown and Concheyro, 2004; Ballent et al., 2004, 2011). Other elements of tethyan affinity have been recognized, such as the typical Tithonian saccocomid microcrinoids (Kietzmann and Palma, 


\section{A Southern Neuquén sector}

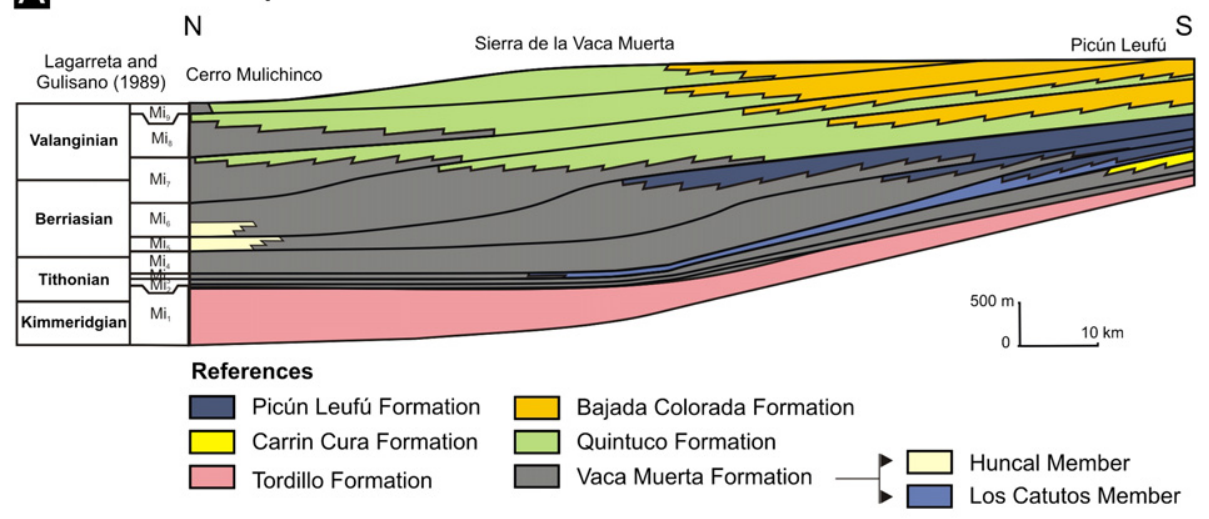

\section{B Central Neuquén sector}

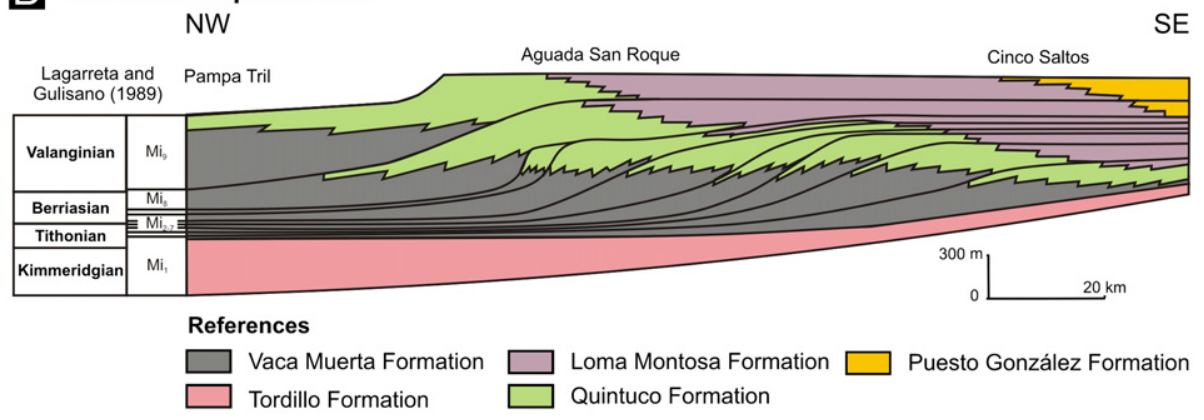

\section{Southern Mendoza sector}

W

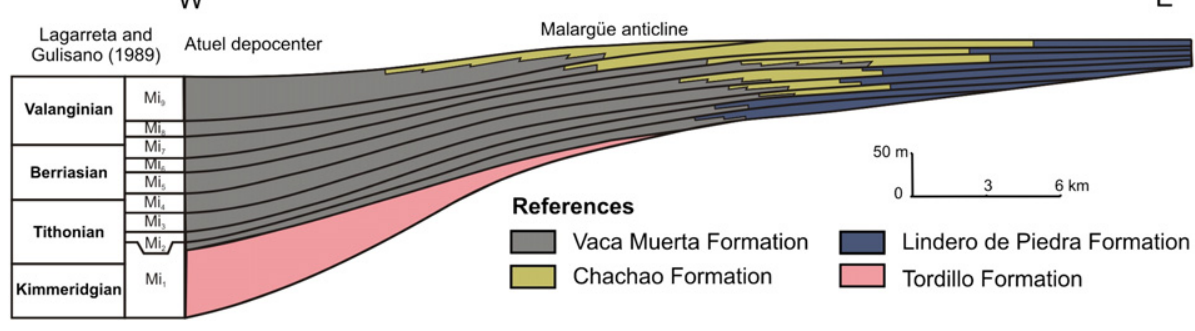

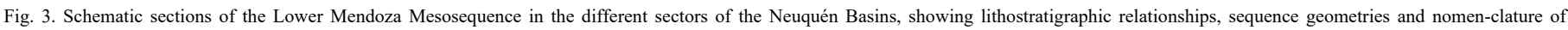

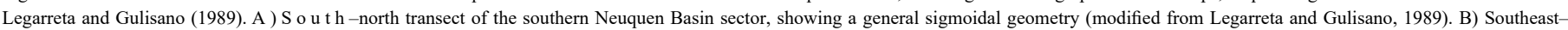

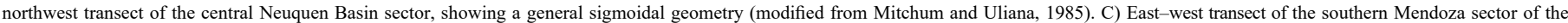
Neuquen Basin, showing a divergent prisms geometry (modified from Legarreta and Gulisano, 1989).

2009b), as well as calpionellids and calcisphaeres (Fernández-Carmona and Riccardi, 1998, 1999; Kietzmann et al., 2011b), although are still under study (Fig. 4). Additionally new stratigraphic knowledge based on cyclostratigraphic studies (Kietzmann, 2011; Kietzmann et al., 2011a) provides new facies correlation and improve orbital scale calibra-tion of ammonite zone.

Ammonite data from the entire studied sedimentary sections point out that the Vaca Muerta Formation was deposited from the lower Tithonian (Virgatosphinctes mendozanus Zone) to lower Valanginian (lowermost part of the Olcostephanus (O.) atherstoni Zone) (Figs. 4, 5).

\section{Methodology}

Detailed sedimentological sections of the Vaca Muerta Formation were measured and described bed-by-bed in ten localities of the south-ern Mendoza sector of the Neuquén Basin, along the Malargüe fold and thrust belt. They include the Arroyo La Manga $(170 \mathrm{~m})$, Cañada Ancha $(350 \mathrm{~m})$, Arroyo Loncoche (316 m), Cuesta del Chihuido (185 m), Bardas Blancas (230 m), Arroyo Rahue $(340 \mathrm{~m})$, Mallín Redondo $(130 \mathrm{~m})$, Cara Cura $(340 \mathrm{~m})$ and Cerro Domuyo (522 m) sections (Fig. 5). Carbonate and siliciclastic facies were analyzed taking into account bed geometry, li-thology, sedimentary structures, fossil content and taphonomic features. Facies were supplemented by petrographic observations based on more than 600 thin sections. We use here a facies code consisting in three letters: First letter refers to texture/lithology (using italic for carbonate lithologies), second letter to main components (in subscript), and third letter to sedimentary structures (Tables 1 and 2). Divisions of sedimenta-ry environments within the carbonate ramp are based in Burchette and Wright (1992).

Time constraints were based on ammonite biozones following the scheme proposed by Riccardi (2008), which represents the biozonation with better temporal resolution, and has proved to be the most practical for field recognition (Fig. 4).

Sequence stratigraphic framework is based on the identification of flooding surfaces, which were identified using juxtaposition and disloca-tion of facies. In fact, the position of the Vaca Muerta Formation in the sed-imentary system does not allow the recognition of sequence boundaries as subaerial exposure surfaces in the sense of Van Wagoner et al.(1990). Nonetheless, stacking pattern and facies tendency are used to recognize sequence stratigraphic trends, where flooding surfaces can be 


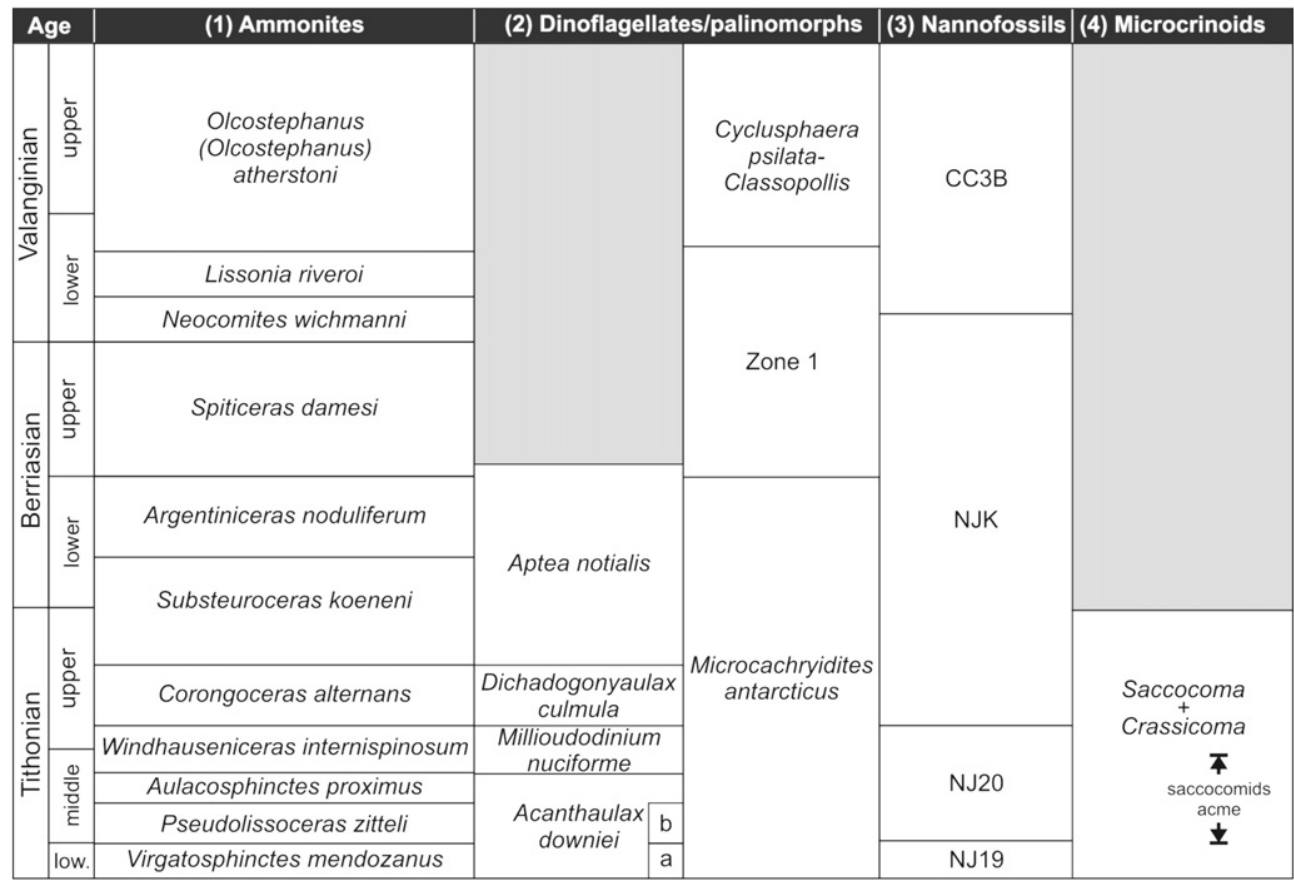

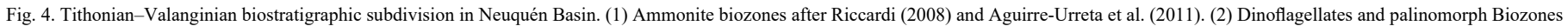

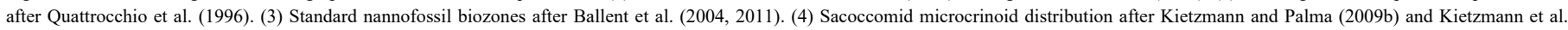
(2010a).

interpreted as correlative conformities of subaerial exposure surfaces, forming coplanar surfaces (e.g., Embry and Johannessen, 1992; Lindsay et al., 1993). Toc values were measured in about 100 marls samples (Arroyo La Manga, Arroyo Loncoche and Arroyo Rahue sections), in order to examine the relationship between organic matter, sedimentary facies and depositional sequences.

\section{Facies analysis}

The Vaca Muerta Formation consists of different facies, which were combined into seven facies associations representing a carbonate ramp depositional system within a middle to distal outer ramp setting. These facies associations are present throughout the entire southern Mendoza area, although in the southwest there are slope facies of an-other depositional system, related to the configuration of the Andean volcanic arc. Facies features and their sedimentary interpretation are summarized in Tables 1 and 2.

\subsection{Facies association 1: Oyster auto-parabiostrome dominated middle ramp}

\subsubsection{Description}

Facies association 1 is represented by low-angle cross-stratified and massive poorly stratified bioclastic rudstones and floatstones $\left(R_{b} l, R_{b} m / g\right.$ and $\left.\mathrm{F}_{\mathrm{b}} \mathrm{m}\right)$ interbedded with bioclastic marls $\left(\mathrm{Mr}_{\mathrm{b}}\right)$ and laminated or bioturbated wackestones $\left(\mathrm{W}_{\mathrm{b}} \mathrm{h}, \mathrm{W}_{\mathrm{b}} \mathrm{b}\right)$. Subordinated centimeter thick lapillite deposits (Lm, $\mathrm{Lg}$ ) also occur. The marl/limestone ratio is $\sim 1: 1$. This facies association is poorly represented in the Vaca Muerta Forma-tion, although it has been recognized in Arroyo Loncoche, Cuesta del Chihuido, and Cara Cura sections (Fig. 5). These oysters accumulations form auto-parabiostromes (sensu Kershaw, 1994) which are up to sev-eral meters thick and have a conspicuous lateral continuity (Figs. 5, 6). Bioclasts include also aragonitic bivalves, serpulids, gastropods, echino-derms, sponge spicules and ammonites. Besides these, dasycladacean algae as well as ostracods, ophiuroid ossicles, brachiopods, foraminifera and calcisphaeres appear sporadically. This facies is also rich in crusta-cean microcoprolites, which form most of the micritic matrix.
Rudstones and floatstones consist of oyster concentrations com-posed mainly of Aetostreon latissimum and/or Liostrea sp. They are typically tabular massive or graded beds ranging from 15 to $25 \mathrm{~cm}$ in thickness, showing transitional to erosive bases, although some beds have low-angle crossstratification. At the base most oyster are articulat-ed and keep in life position. Towards the top the packing becomes denser, increasing the degree of disarticulation and fragmentation, and the pro-portion of ammonites and serpulids, which have random arrangement.

The top of the individual beds are frequently bioturbated by Thalassinoides, including Thalassinoides suevicus (Rieth), which form extended galleries of up to $50 \mathrm{~cm}$ long, and Thalassinoides paradoxicus (Woodward), with galleries of 5-20 $\mathrm{cm}$ in depth and passive bioclastic infilling.

Laminated wackestones $\left(\mathrm{W}_{\mathrm{b}} \mathrm{h}\right)$ are generally bioturbated on top by Taenidium, Diplocraterion, Rhizocorallium and/or Thalassinoides. They include small disarticulated ostracods, ophiuroid ossicles, dasycladacean algae, calcisphaeres, crustacean microcoprolites, as well as epistominid and textularid foraminifera (Fig. 6). Bioturbated wackestones $\left(\mathrm{W}_{\mathrm{b}} \mathrm{b}\right)$ are similar in textures, but highly bioturbated by Thalassinoides forming large galleries with boxwork type structures.

Bioclastic marls $\left(\mathrm{Mr}_{\mathrm{b}}\right)$ are rich in oyster in life position, serpulids and rynchonellid brachipods.

\subsubsection{Interpretation}

Bioclastic rudstones $\left(\mathrm{R}_{\mathrm{b}} \mathrm{m} / \mathrm{g}\right)$ and floatstones $\left(\mathrm{F}_{\mathrm{b}} \mathrm{m}\right)$ are probably related to bottom remobilization occurring during major storms, as sug-gested by erosive bases, high fragmentation of bioclasts, shell nests and random shell orientations, so they could be interpreted as proximal tempestites.

Low-angle cross-stratified deposits $\left(\mathrm{R}_{\mathrm{b}} \mathrm{l}\right)$ are interpreted as accretionary bioclastic bars probably related to storm-induced unidi-rectional flows (e.g. Bádenas and Aurell, 2001; Flügel, 2004). Presence of steinkerns is typically associated with fluctuating sedimentation rates, reworking and redepositional processes, within the winnowing zone (Flügel, 2004). Moreover coexistence of endobenthic and epibenthic organisms is also evidence of alternation in hydrodynamic and energy conditions (Kietzmann and Palma, 2009a). 


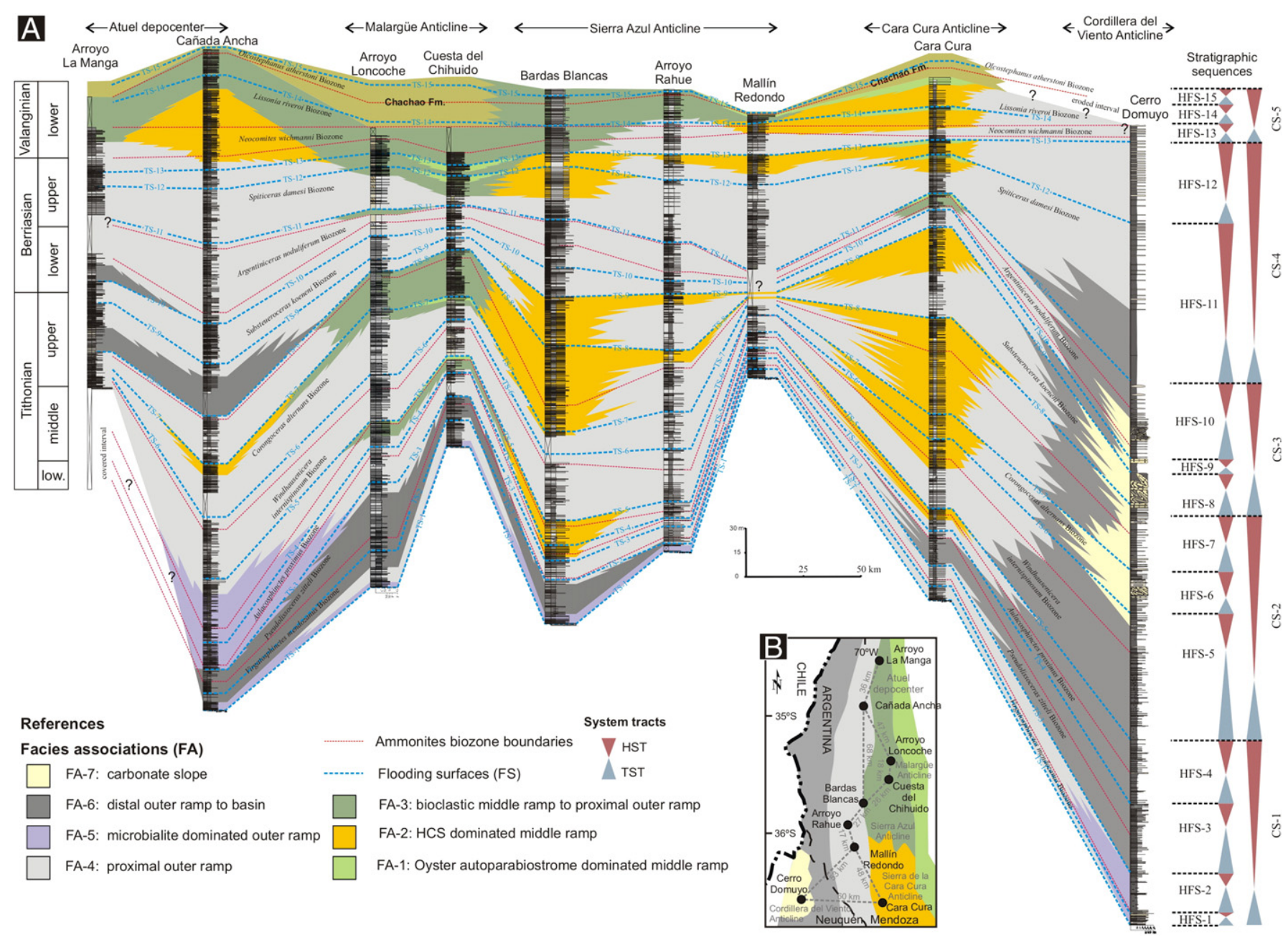

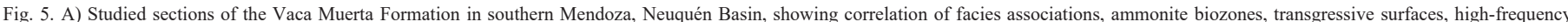

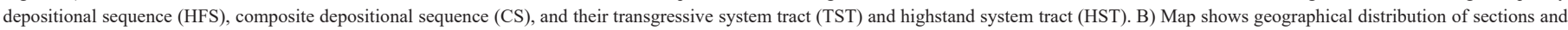
paleogeographical facies distribution for late Tithonian-early Berriasian.

Table 1

Facies distribution in the Vaca Muerta Formation. References: (MRF) most representative facies, (RF) representative facies, (SF) subordinate facies, (VF) volcaniclastic facies.

\begin{tabular}{|c|c|c|c|c|c|c|c|c|c|c|}
\hline & \multicolumn{7}{|c|}{ Facies association } \\
\hline & & & & 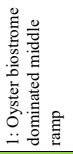 & 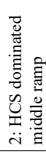 & 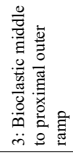 & 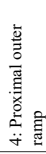 & 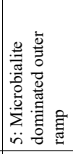 & 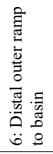 & 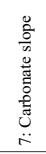 \\
\hline \multirow{14}{*}{ 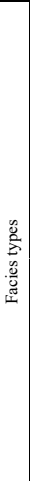 } & & $\begin{array}{l}\text { Cross-stratified } \\
\text { bioclastic rudstone }\end{array}$ & $R_{\mathrm{b}} \mathrm{l}$ & $\mathrm{RF}$ & & & & & & \\
\hline & & $\begin{array}{l}\text { Bioclastic rudstone } \\
\text { Bioclastic floatstone }\end{array}$ & $\frac{R_{\mathrm{b}} \mathrm{m} / \mathrm{g}}{F_{\mathrm{m}}}$ & MRF & & & & & & \\
\hline & 幽 & $\begin{array}{l}\text { Multievent bioclastic } \\
\text { floatstone/rudstone }\end{array}$ & $R F_{\mathrm{b}} \mathrm{m}$ & & RF & MRF & SF & & & \\
\hline & 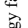 & HCS grainstrone & $G_{\mathrm{pp}} \mathrm{HCS}$ & & MRF & & & & & \\
\hline & 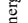 & Laminated packstone & & & $\mathrm{RF}$ & MRF & MRF & $\mathrm{RF}$ & $\mathrm{SF}$ & \\
\hline & 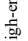 & $\begin{array}{l}\text { Ripple laminated } \\
\text { packstone }\end{array}$ & $\mathrm{P}_{\mathrm{p}} \mathrm{r}$ & & & & & & MRF & \\
\hline & 五 & $\begin{array}{l}\text { Fine grained sandy } \\
\text { bioclastic packstones }\end{array}$ & $\begin{array}{l}P_{\mathrm{b} t} \mathrm{~m}, \\
P_{\mathrm{bt}} \mathrm{h}\end{array}$ & & & & & & & MRF \\
\hline & & Intraclastic breccias & $B_{i}$ & & & & & & & SF \\
\hline & \multirow{6}{*}{ 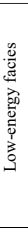 } & $\begin{array}{l}\text { Planar microbialite } \\
\text { bindstones }\end{array}$ & $B_{\mathrm{m}} 1$ & & $\mathrm{SF}$ & & & MRF & & \\
\hline & & $\begin{array}{l}\text { Bioturbated } \\
\text { wackestones }\end{array}$ & $W_{\mathrm{b}} \mathrm{b}$ & SF & $\mathrm{RF}$ & $\mathrm{SF}$ & & & & \\
\hline & & Laminated wackestone & $W_{\mathrm{b}} \mathrm{h}$ & SF & & $\mathrm{SF}$ & \multirow[b]{2}{*}{$\mathrm{RF}$} & & & \\
\hline & & $\begin{array}{l}\text { Radiolaritic laminated } \\
\text { wackestone }\end{array}$ & $W_{\mathrm{r}} \mathrm{h}$ & & & & & $\mathrm{RF}$ & SF & \\
\hline & & Bioclastic marls & $\mathrm{Mr}_{\mathrm{b}}$ & $\mathrm{RF}$ & $\mathrm{RF}$ & $\mathrm{RF}$ & & & & \\
\hline & & Laminated marls & Mrh & & & & $\mathrm{RF}$ & $\mathrm{RF}$ & $\mathrm{RF}$ & $\mathrm{RF}$ \\
\hline
\end{tabular}

\begin{tabular}{|c|l|c|c|c|c|c|c|c|c|}
\hline \multirow{2}{*}{ VF } & Lapillites & $\mathrm{Lm} / \mathrm{g}$ & $\mathrm{SF}$ & $\mathrm{SF}$ & $\mathrm{SF}$ & & & & SF \\
\cline { 2 - 9 } & Tuff & $\mathrm{Tm} / \mathrm{g}$ & & $\mathrm{SF}$ & & SF & SF & SF & SF \\
\hline
\end{tabular}

Laminated wackestones $\left(\mathrm{W}_{\mathrm{b}} \mathrm{h}\right)$ and marls $\left(\mathrm{Mr}_{\mathrm{b}}\right)$ were deposited from suspension in a moderate low energy setting, and represent zones unaffected by storm waves or other currents, probably related to fair-weather periods.

Preservation only of lower portions of Thalassinoides galleries in bioturbated wackestones $\left(\mathrm{W}_{\mathrm{b}} \mathrm{b}\right)$ suggests recurrent erosive processes related to storm events. On the other hand, T. paradoxicus indicates ramp stages with low sedimentation rates allowing early substrate con-solidation, and subsequent erosion and passive infil $1 \mathrm{i} n \mathrm{~g} \mathrm{~d} \mathrm{u} \mathrm{ri} \mathrm{ng} \mathrm{s} \mathrm{t} \mathrm{o} \mathrm{r} \mathrm{m} \mathrm{s} \mathrm{(Myrrow,} \mathrm{1995).}$

Presence of burrowing organisms indicates sea floor aerobic condi-tions. The trace fossil assemblage is indicative of the Cruziana ichnofacies, which characterizes low-energy environments, colonized by deposit feeders and also by mobile carnivores, omnivores and suspension feeders (Pemberton et al., 1992; MacEachern et al., 2008).

Facies association 1 is interpreted as deposits of a well-oxygenated middle ramp, between the storm-wave base and the fair-weather wave base.

\subsection{Facies association 2: HCS dominated middle ramp}

\subsubsection{Description}

Facies association 2 is represented by an alternation of low-energy facies similar to those of facies association 1 , including bioclastic marls 
Table 2

Facies in the Vaca Muerta Formation, with summarized lithological description and sedimentary interpretation.

\begin{tabular}{|c|c|c|c|c|c|c|}
\hline Facies type & Code & $\begin{array}{l}\text { Sedimentary structures - } \\
\text { trace fossils }\end{array}$ & $\begin{array}{l}\text { Geometry - } \\
\text { contacts - color } \\
- \text { thickness }\end{array}$ & Particles types — taphonomy & Interpretation of sedimentary processes & $\begin{array}{r}\text { Occurrence in } \\
\text { sedimentary } \\
\text { environment }\end{array}$ \\
\hline Cross-stratified bioclastic rudstone & $\mathrm{R}_{\mathrm{b}} \mathrm{l}$ & Low angle cross-stratification & $\begin{array}{l}\text { Tabular - } \\
\text { transitional to } \\
\text { erosive bases - } \\
\text { gray to brown }-15 \\
\text { to } 25 \mathrm{~cm}\end{array}$ & $\begin{array}{l}\text { Oysters are dominant (Aetostreon latissimum). Eriphyla, } \\
\text { Panopaea, rotularid serpulids, ammonites and rynchonellids } \\
\text { are also common. Pellets and steinkerns are common. - } \\
\text { Articulation of valves is high, fragmentation and abrasion } \\
\text { are low. Evidence of bioerosion or encrustation are rare }\end{array}$ & $\begin{array}{l}\text { Accretionary bioclastic bars above the storm wave base. } \\
\text { Fluctuatingsedimentation rates, reworking and } \\
\text { redepositional processes, withinthe winnowing zone. } \\
\text { Coexistence of endobenthic and epibenthic organisms } \\
\text { evidence alternating hydrodynamic and energy conditions }\end{array}$ & $\begin{array}{l}\text { Middle ramp } \\
\text { (facies } \\
\text { association 1) }\end{array}$ \\
\hline Bioclastic rudstone & $\begin{array}{l}\mathrm{R}_{\mathrm{b}} \mathrm{m} \\
\mathrm{R}_{\mathrm{b}} \mathrm{g}\end{array}$ & $\begin{array}{l}\text { Massive, normal graded - } \\
\text { Thalassinoides }\end{array}$ & $\begin{array}{l}\text { Tabular - } \\
\text { transitional to } \\
\text { erosive bases - } \\
\text { gray to brown - } 15 \\
\text { to } 20 \mathrm{~cm}\end{array}$ & $\begin{array}{l}\text { Oysters are dominant (Aetostreon latissimum, Liostrea). } \\
\text { Eriphyla, Panopaea, rotularid serpulids, ammonites, } \\
\text { rynchonellids and calcisphaeres are also common. Pellets } \\
\text { and steinkerns are common. - Articulation of valves is } \\
\text { high, fragmentation and abrasion are low. Evidence of } \\
\text { bioerosion or encrustation are rare }\end{array}$ & $\begin{array}{l}\text { Alternating hydrodynamic and energy conditions. } \\
\text { Reworking associated with storm oscillatory flows. }\end{array}$ & $\begin{array}{l}\text { Middle ramp to } \\
\text { proximal outer } \\
\text { ramp (facies } \\
\text { associations1, } 2 \\
\text { and 3) }\end{array}$ \\
\hline Bioclastic floatstone & $\mathrm{F}_{\mathrm{b}} \mathrm{m}$ & Massive - Thalassinoides & $\begin{array}{l}\text { Tabular - sharp } \\
\text { and erosive bases } \\
\text { - gray to brown - } \\
10 \text { to } 25 \mathrm{~cm}\end{array}$ & $\begin{array}{l}\text { Pelloidal matrix. Oysters (Aetostreon, Deltoideum, Liostrea), } \\
\text { Eriphyla, L u c i n a, Grammatodon, rotularid serpulids, } \\
\text { ammonites, gastropods, steinkerns, echinoderms, and } \\
\text { calcisphaeres. - Low degree of articulation, fragmentation }\end{array}$ & $\begin{array}{l}\text { Related with bottom remobilization during major storms } \\
\text { (proximal tempestites). }\end{array}$ & $\begin{array}{l}\text { Middle ramp to } \\
\text { proximal outer } \\
\text { ramp (facies } \\
\text { associations1, } 2 \\
\text { and 3) }\end{array}$ \\
\hline $\begin{array}{r}\text { Multi-eventbioclastic } \\
\text { floatstone/rudstone }\end{array}$ & $R F_{\mathrm{b}} \mathrm{m}$ & $\begin{array}{l}\text { Massive, normal graded - } \\
\text { exhumed Thalassinoides } \\
\text { galleries with passive infilling }\end{array}$ & $\begin{array}{l}\text { Tabular - sharp } \\
\text { and erosive bases } \\
\text { - gray to brown - } \\
10 \text { to } 40 \mathrm{~cm}\end{array}$ & $\begin{array}{l}\text { andabrasion. Scarce evidence of bioerosion or encrustation } \\
\text { Peloidal Matrix. Abundantoysters (Aetostreon, Deltoideum, } \\
\text { Ceratostreon), epifaunal and infaunal bivalves (pectinids, } \\
\text { trigonids, Lucina, Eriphyla, Cuccullea and Grammatodon). } \\
\text { Rynchonellids, gastropods, serpulids (Rotularia), ammonites, } \\
\text { nautiloids, belemnites, epistominid foraminifera, } \\
\text { calpionellids and calcisphaeres. Some also includes } \\
\text { calcareous algae and pumiceous fragments. Chaotic } \\
\text { distribution of bioclast, ammonites often imbricated. - } \\
\text { Articulation and fragmentation are low. Oysters with } \\
\text { bioerosion. At bases shells are concordant and convex-down, } \\
\text { while to de top are frequently convex-up, oriented }\end{array}$ & $\begin{array}{l}\text { Relatedwith bottom remobilization occurring duringmajor } \\
\text { storms (proximal tempestites). }\end{array}$ & $\begin{array}{l}\text { Middle ramp to } \\
\text { proximal outer } \\
\text { ramp (facies } \\
\text { associations2, } 3 \\
\text { and 4) }\end{array}$ \\
\hline HCS grainstones & GpiHCS & $\begin{array}{l}\text { Hummocky cross- } \\
\text { stratification - Helminthopsis, } \\
\text { Planolites and Chondrites }\end{array}$ & $\begin{array}{l}\text { tabular } \\
\text { Sharp and erosive } \\
\text { bases } \\
\text { Gray to brown } \\
20 \text { to } 60 \mathrm{~cm}\end{array}$ & $\begin{array}{l}\text { perpendicular to stratification or stacked forming nets } \\
\text { Rich in micritic intraclasts and crustacean microcoprolites. } \\
\text { Bivalve fragments, gastropods, benthic foraminifera } \\
\text { (Epistomina, Lenticulina, Siphovalvulina and } \\
\text { Pseudocyclammina), gastropod internal molds and small } \\
\text { bone fragments are common. - Remains of Saccocoma, }\end{array}$ & $\begin{array}{l}\text { Accretionary hummocks generated from storm-related os- } \\
\text { cillatory flows with a small unidirectional component. }\end{array}$ & $\begin{array}{l}\text { Middle ramp } \\
\text { (facies } \\
\text { association 2) }\end{array}$ \\
\hline Bioturbated wackestones & $\mathrm{W}_{\mathrm{b}} \mathrm{b}$ & $\begin{array}{l}\text { Massive, horizontal lamination } \\
\text { - well-developed boxwork- } \\
\text { type Thalassinoides galleries } \\
\text { (exhumed) }\end{array}$ & $\begin{array}{l}\text { Tabular - sharp } \\
\text { irregular } \\
\text { contacts - brown } \\
\text { to gray }-20 \text { to } \\
45 \mathrm{~cm}\end{array}$ & $\begin{array}{l}\text { calpionellids and calcisphaeresare also common } \\
\text { Disarticulated infaunal bivalves, shells and internal molds of } \\
\text { gastropods, echinoderm and Saccocoma remains, } \\
\text { ammonites, epistominid foraminifera, calpionellids, }\end{array}$ & $\begin{array}{l}\text { Deposition from suspension (fall-out and resuspended } \\
\text { sediments by storms) in a moderate low energy setting. Lower } \\
\text { portions of Thallasinoides galleries are preserved. Recurrent } \\
\text { erosive processes related with storm events }\end{array}$ & $\begin{array}{l}\text { Middle ramp to } \\
\text { proximal outer } \\
\text { ramp (facies } \\
\text { associations1, } 2 \\
\text { and 3) }\end{array}$ \\
\hline Ripple laminated packstone & $\mathrm{P}_{\mathrm{p}} \mathrm{r}$ & $\begin{array}{l}\text { Ripple lamination. Occasionally } \\
\text { sole marks and hummocky-like } \\
\text { cross strati-fied structures }\end{array}$ & $\begin{array}{l}\text { Tabular - sharp } \\
\text { and erosive } \\
\text { bases - dark Gray } \\
\text { to black - } 5 \text { to }\end{array}$ & $\begin{array}{l}\text { calcisphaeres, and abundant pellets. } \\
\text { Peloids, well sorted in fine sand size. Scarce infaunal bivalves } \\
\text { andechinoderm fragments. Silt size terrigens (quartz and } \\
\text { plagioclase) are abundant. }\end{array}$ & Storm-generated turbidity flows & $\begin{array}{l}\text { Distal outer } \\
\text { ramp to basin } \\
\text { (facies } \\
\text { association 6) }\end{array}$ \\
\hline
\end{tabular}



Planolites, Chondrites,

Laminated wackestone

Radiolaritic laminated wackestone

$\mathrm{W}_{\mathrm{b}} \mathrm{h} \quad$ Horizontal lamination -

\section{$\mathrm{W}_{\mathrm{r}} \mathrm{h} \quad$ Horizontal lamination}

Bioclastic marls

Marls

Fine grained sandy bioclastic packstones

Lapillites
Lm, Lg Massive, inverse graded Thalassinoides.

Tm, Massive, inverse graded Tg Rhizocorallium
Millimeter-scale microbial lamination. Roll-up structures are common - rare Thalassinoides Lumbricaria Taenidium, Diplocraterium, Rhizocorallium Thalassinoids

Massive

Tabular — bases are sharp and sometimes irregular - gray to brown -210 to $30 \mathrm{~cm}$

Tabular - sharp

Tabular -

contacts - gray to black -10 to $60 \mathrm{~cm}$

Tabular — sharp and planarbrown -10 to $25 \mathrm{~cm}$ Tabular - sharp and planar - dark gray to black -2 to $30 \mathrm{~cm}$

Horizontal lamination, concretions Tabular — sharp (early diagenetic, withsimilar and planar fossil content and textural features browntogray- 10 of limestones) to $30 \mathrm{~cm}$

(ental lamination, concretions Tabular - sharp fossil content and textural features and planar - dark and planar - dark
gray to black - 15 Massive or poorly developed to $30 \mathrm{~cm}$ lamination

Lentiform - sharp and planar - dark gray to black -10 to $50 \mathrm{~cm}$

Mantiform - sharp and planar - dark gray to b

$30 \mathrm{~cm}$ Tabular - sharp planar - gray to $15 \mathrm{~cm}$

Tabular - sharp

pabular - sharp erosive bases -
Peloidal (crustacean microcoprolites) or intraclastic. Well sorted in medium sand size. Subangular toangular micritic clast. Ammonites, articulated and disarticulated bivalves,

lingulid brachiopods, gastropods, saccocoma concentrations, calpionellids and calcisphaeres.

Defined by alternating layers of translucent calcite, often internally showing irregular sub-horizontal, and finegrained wackestones with foraminifers, radiolarims, calcisphaeres, and small peloids, or peloidal packstons, with foraminifers, Mic foric Sme

Small disarticulated ostracods, ophiuroid ossicles, epistominid and textularid foraminifera, calpionellids and calcisphaeres

Abundant radiolarians. Rare calcisphaeres. Ammonites, aptychi, infaunal bivalves (Eriphyla and Lucina), and serpulids. None of these elements are in life position. Organic matter content is high (3 to $5 \%$ ). They contain also some laminae of microbial origin.

Rich in oyster, serpulids, disarticulated infaunal bivalves, rynchonellid brachiopods, and ammonites

Disarticulated thin-shelled oysters, ammonites and abundant fish scales. Rarely also belemnites, trunks and branches

Echinoderm fragments, dasycladacean algae, infaunal bivalves, oolite grainstone intraclasts, and fine sand size terrigenous

Grain-supported, monomictic. Clast are micritic (radiolaritic wackestones and mudstones), of pebble size, angular to subangular.

Abundant pumiceous fragments and finesand size micritic andsubordinately silt size terrigenous

Abundant glass shards and pumiceous fragments

Open ocean conditions. Times of low sedimentation rate. The intercalation of peloidal packstones, and roll-up structures, related to ep

Deposition from suspension in a moderate low energy setting. Only the lower portions of the Thallasinoides galleries are preserved suggesting recurrent erosive processes related with storm events

Mainly deposited by fall out of fine muddy sediments. Nasselaria spumellarian ratio suggestapoorly oxigenated setting

Deposition from suspension (fall-out and resuspended sediments by storms) in a moderate low energy setting

Deposition from suspension (fall-out and resuspended sediments by storms) in a moderate low energy setting

Turbidity flows

Non-cohesive debris-flow deposits

Deposited from floating rafts of air fall pumice, and low density

Ash fall and/or low density turbidity flows
Middle ramp to basin (facies 4, 5 and 6 )

Middle to oute ramp (facies association 2 and 5)

Middle to outer ramp (facies association 3 and 4)

Outer ramp to basin (facies association 4,5 and 6)

Middle to outer ramp (facies association 1,2 and 3)

Outer ramp to slope (facies

5,6 and 7 )

Slope (facies association 7

Slope (facies association 7

Middle ramp to slope (facies association 3,4 associatio
and 7)
Outer ra and 7) Outer ramp to
slope (facies slope (facies 6 and 7 ) 

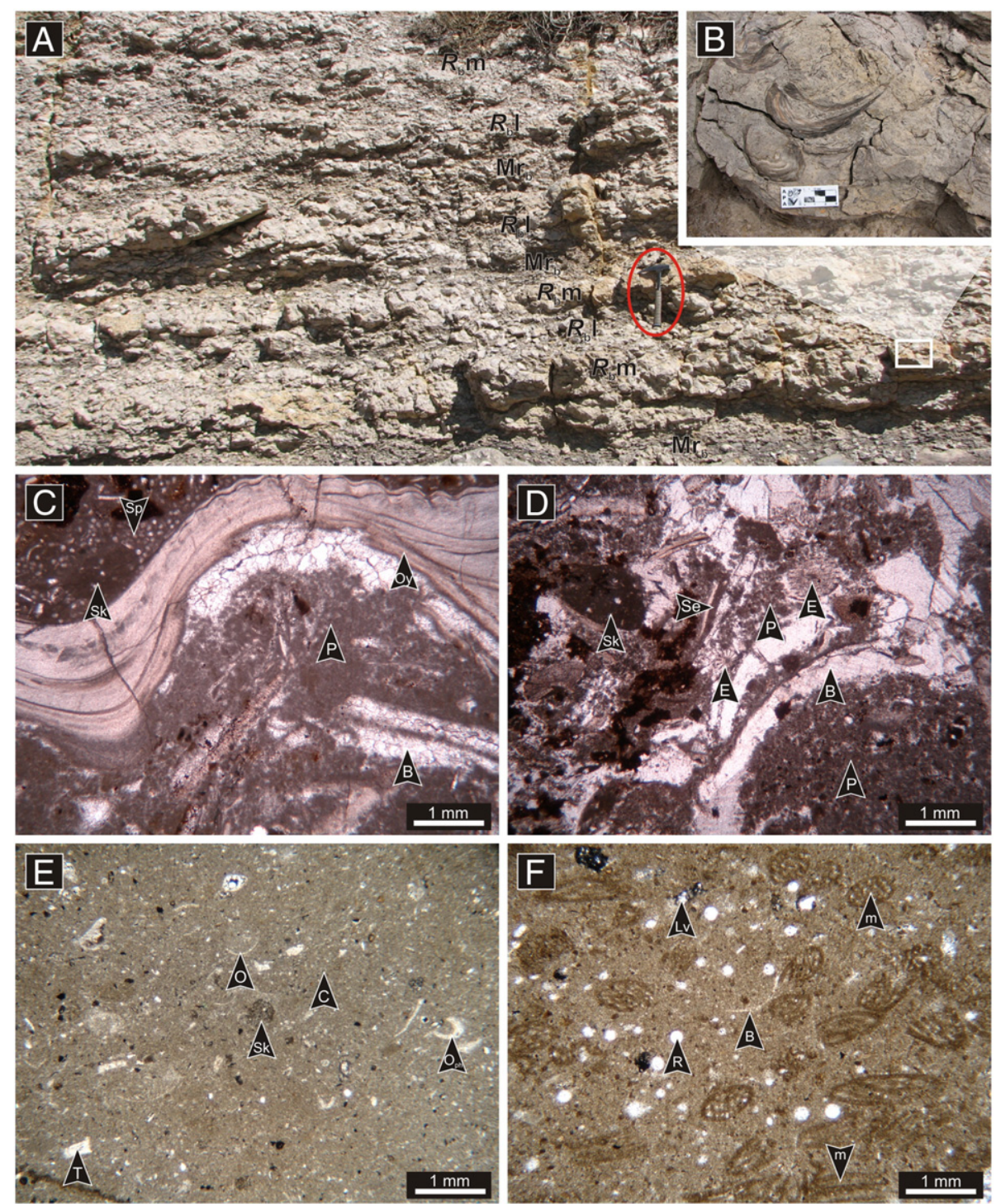

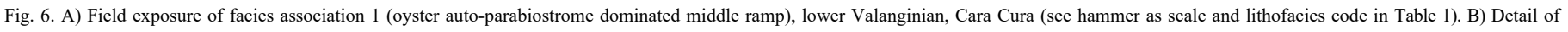

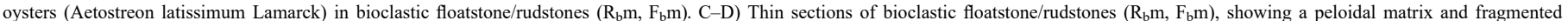

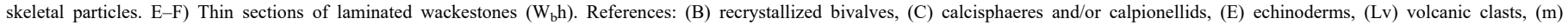

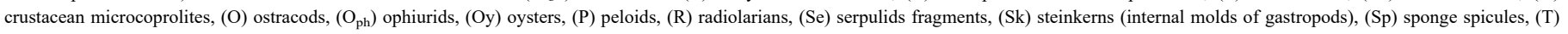
terrigens

$\left(\mathrm{Mr}_{\mathrm{b}}\right)$ and bioturbated wackestones $\left(\mathrm{W}_{\mathrm{b}} \mathrm{b}\right)$, and high-energy facies, including hummocky cross-stratified grainstones $\left(\mathrm{G}_{\mathrm{pi}} \mathrm{HCS}\right)$, laminated packstones $\left(\mathrm{P}_{\mathrm{pi}} \mathrm{h}\right)$, and massive to graded bioclastic floatstones/rudstones $\left(\mathrm{RF}_{\mathrm{b}} \mathrm{m}\right)$. There are also occasional planar microbialite (Bm) tuffs (Tm, Tg) and lapillite ( $\mathrm{Lm}, \mathrm{Lg})$ beds (Fig. 7). The marl/limestone ratio is $\sim 1: 1$. Facies association 2 is very well exposed in the upper part of the Cañada Ancha section, as well as in the Bardas Blancas and Cara Cura sections (Fig. 5). This facies association is more common than traditionally accepted for the Vaca Muerta Formation, and in some sections is the most frequent (e.g. Kietzmann and Palma, 2011).

Bioturbated wackestones $\left(\mathrm{W}_{\mathrm{b}} \mathrm{b}\right)$ occurs in nodular beds with abun-dant $\mathrm{T}$. suevicus, forming large galleries with boxwork type structures. Trace fossils are exhumed galleries, preserving only the lower levels. Bioclastic marls $\left(\mathrm{Mr}_{\mathrm{b}}\right)$ are well laminated and rich in oyster fragments. Particles in low-energy facies are dominated by pellets (crustacean microcoprolites), while bioclasts are usually infaunal bivalves, gastro-pods, echinoderms, Saccocoma remains, ammonites, foraminifera, calcisphaeres and radiolarians.
The hummocky cross-bedding grainstones $\left(\mathrm{G}_{\mathrm{pi}} \mathrm{HCS}\right)$ can grade later-ally in horizontal lamination. Wavelengths range from 25 to $150 \mathrm{~cm}$ (Fig. 7A-D). These facies are rich in micritic intraclasts and crustacean microcoprolites, and contains bivalve fragments, gastropods, phospha-tized gastropod steinkerns, benthic foraminifera. Trace fossil are repre-sented by Helminthopsis, Planolites, a n d Chondrites.

Laminated packstones are peloidal or intraclastic $\left(\mathrm{P}_{\mathrm{pi}} \mathrm{h}\right)$. Fossil con-tent include ammonites, articulated and disarticulated bivalves, lingulid brachiopods, gastropods, phosphatized gastropod steinkerns, which are chaotically distributed or deposited commonly in discrete levels.

Bioclastic floatstones/rudstones $\left(\mathrm{RF}_{\mathrm{b}} \mathrm{m}\right)$ consist of multi-event concentrations rich either in oysters and other bivalves, rynchonellids, gas-tropods, serpulids, ammonites, nautiloids, belemnites, epistominid and agglutinated foraminifera, calpionellids, calcisphaeres, and/or calcare-ous algae and pumiceous fragments (Fig. 7E-F). Deposits are character-ized by a chaotic distribution of bioclasts. Bioturbation is rare but can occur as exhumed galleries of Thalassinoides and Planolites tubes filled with sediments similar to those of the surrounding matrix. 

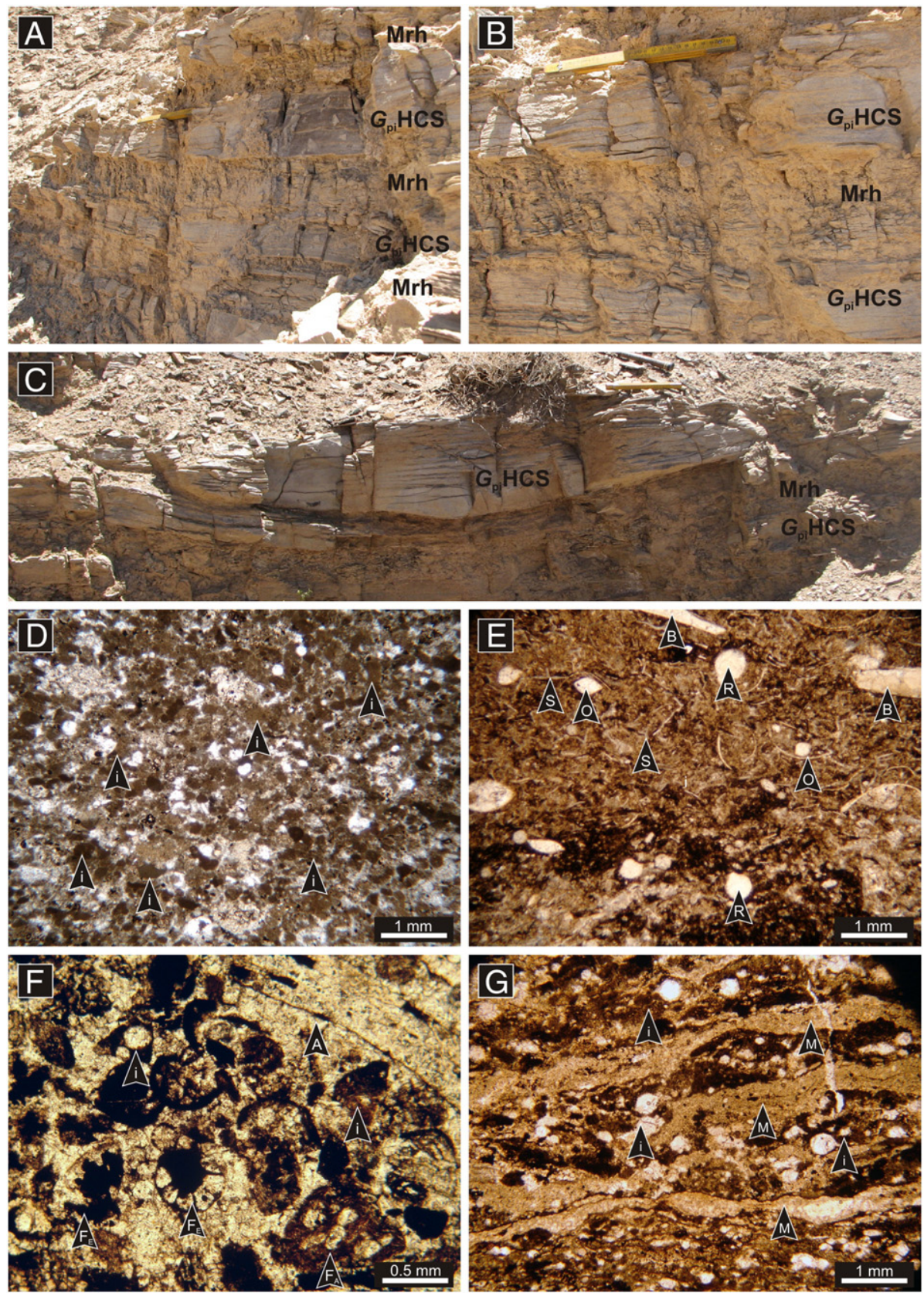

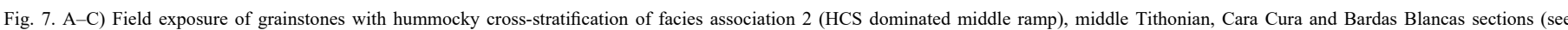

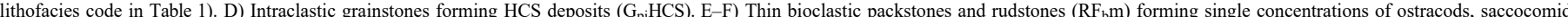

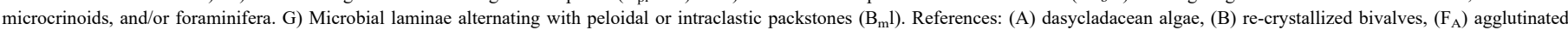
foraminifera, $\left(F_{E}\right)$ epistominid foraminifera, (i) intraclast, $(\mathrm{M})$ microbial laminae, $(\mathrm{O})$ ostracods, $(\mathrm{R})$ radiolarians, $(\mathrm{S})$ sacoccomid microcrinoid ossicles.

Planar microbialites $(\mathrm{Bm})$ form laterally persistent beds with thicknesses of several decimeters. The most evident feature is a conspicuous horizontal to sub-horizontal lamination of submillimeter-to millimeter-scale of rich organic matter micritic laminae and fine-grained peloidal wackestones or packstones with foraminifers, radiolar-ians and calcisphaeres (Fig. 7G). Some laminae are rich in microbialite intraclast accumulations and roll-up structures.

Lapillite deposits are centimeter thick, massive or graded (Lm, Lg), with sharp and planar bases. They are composed by coarse sand to granule size pumiceous fragments. Tuff $(\mathrm{Tm}, \mathrm{Tg})$ are centimeter thick tabular gray to greenish carbonates beds of crystalline appearance. They consist of a crystalline calcite mosaic, with crystals of several millimeters, but particles consists of abundant glass shards and pumi-ceous fragments.

\subsubsection{Interpretation}

Hummocky cross-stratified grainstones $\left(\mathrm{G}_{\mathrm{pi}} \mathrm{HCS}\right)$ are interpreted as deposits of accretionary hummocks generated from storm-related oscil-latory flows with a small unidirectional component, while massive to graded bioclastic floatstones/rudstones $\left(\mathrm{RF}_{\mathrm{b}} \mathrm{m}\right)$ represent bioclastic tempestites originated by turbidite-like gravity flows (e.g. Monaco, 1992; Molina et al., 1997; Kietzmann and Palma, 2011).

Bioturbated wackestones, laminated packstones, and marls indicate deposition after reworking of the seafloor by action of storm waves. Pelloidal accumulations come probably from the unroofing of crusta-cean galleries. Indeed, the sea floor would have similar characteristics to those of the Bahamas or the Florida Keys (e.g. Warme, 1967; Tedesco and Wanless, 1991), where callianassids generate an irregular topogra-phy composed of conical mounds connected with large horizontal 

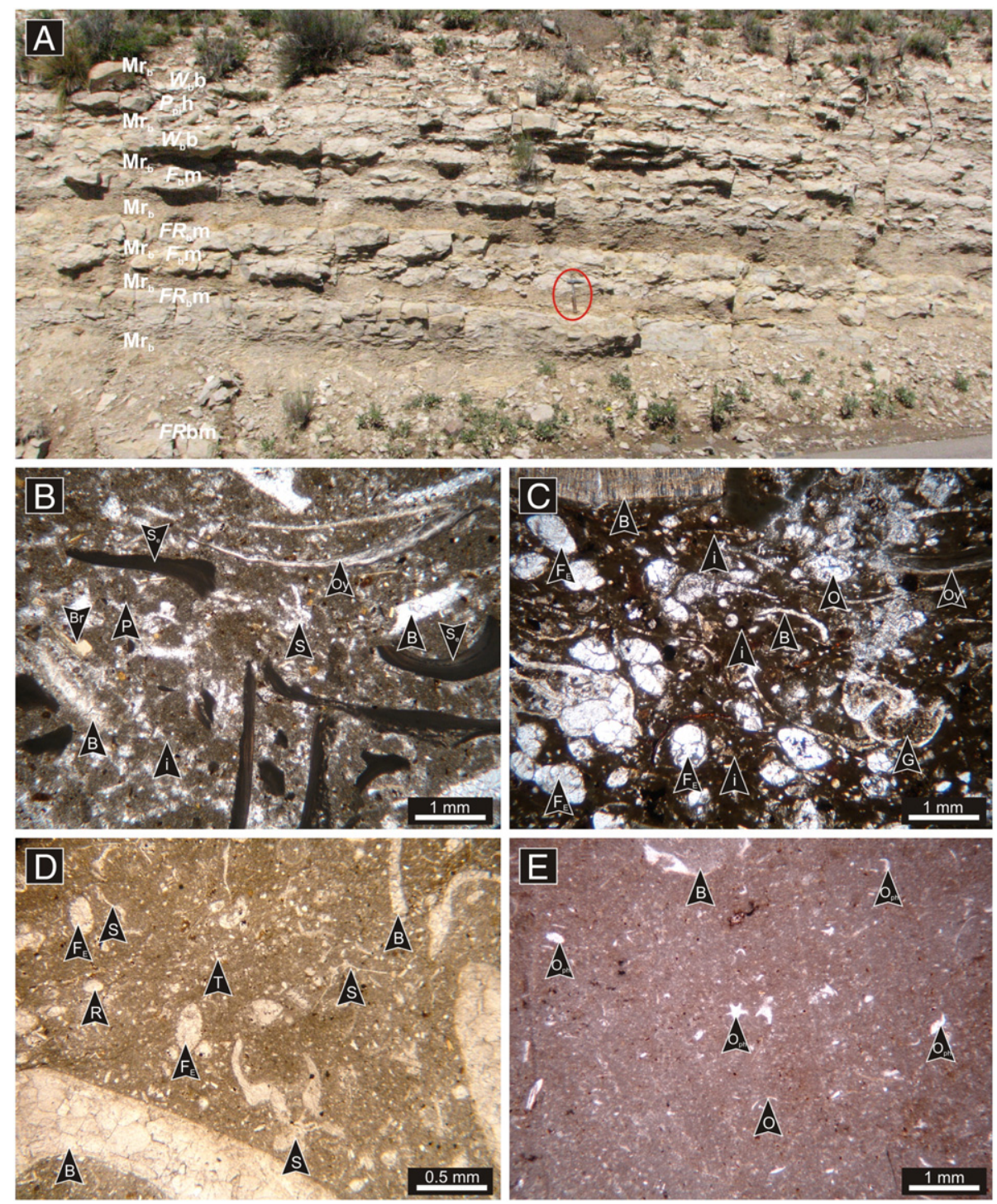

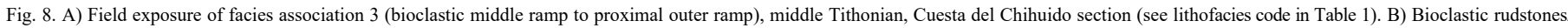

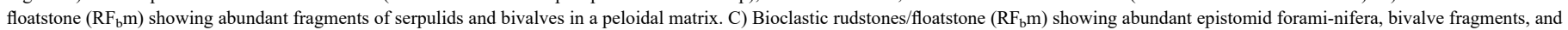

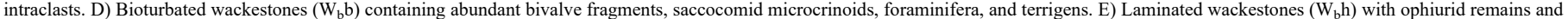

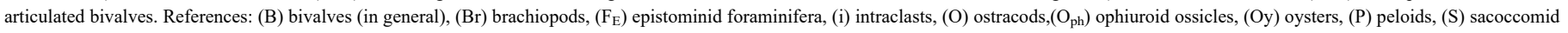
microcrinoid ossicles, $\left(\mathrm{S}_{\mathrm{e}}\right)$ serpulid fragments, $(\mathrm{T})$ terrigens.

burrow systems. Low energy waters should have favored proliferation of crustaceans, which are responsible for the pelletization of large quantities of muddy sediments, occurring in the substrate or in suspension (Pryor,

1975).

Microbialite beds indicate periods of low sedimentation rate, allowing proliferation of microbial mats in a relative low energy setting, episodically affected by storm-related high energy events. Similar deposits were described by Schieber $(1998,1999)$ from the Mid-Proterozoic Belt Supergroup of Montana, as well as from the Upper Devonian Sonyea Group of New York.

Tuff deposits were probably deposited from non-cohesive low density turbidites, while massive and inverse graded lapillite facies deposited probably from floating rafts of air fall pumice. Trace fossils indicate alternating energy regimes and a relatively well oxygenated substrate. The association of Taenidium, Thalassinoides, Diplocraterion and Rhizocoralliun is indicative of the Skolithos ichnofacies, which sug-gests colonization of storm beds by a community of opportunistic organ-isms in a post-event, high-stress, physically controlled environment. On the other hand, the association of Helminthopsis?, Planolites, Chondrites and Thalassinoides is indicative of the Cruziana ichnofacies, which characterizing low-energy environments, and suggesting substrate colonization during fair-weather stages (Pemberton et al., 1992).

Facies association 2 is interpreted as deposited above the storm-wave base in a well-oxygenated middle ramp.

\subsection{Facies association 3: bioclastic middle ramp to proximal outer ramp}

\subsubsection{Description}

Facies association 3 is characterized by the alternation of similar lowenergy facies to previous facies association, including bioturbated wackestones $\left(\mathrm{W}_{\mathrm{b}} \mathrm{b}\right)$, laminated wackestones $\left(\mathrm{W}_{\mathrm{b}} \mathrm{h}\right)$, bioclastic marls $\left(\mathrm{Mr}_{\mathrm{b}}\right)$ and laminated marls (Mrh), and high-energy facies, made up of bioclastic rudstones/ floatstones $\left(\mathrm{RF}_{\mathrm{b}} \mathrm{m}\right)$, and laminated packstones $\left(\mathrm{P}_{\mathrm{pi}} \mathrm{h}\right)$ (Fig. 8A). Subordinated centimeter thick lapillite deposits $(\mathrm{Lm}, \mathrm{Lg})$ also occur. The marl/limestone ratio is $\sim 2: 1$. This facies as-sociation is well represented in the Arroyo Loncoche and Cuesta del Chihuido sections, as well as in the lower Valanginian of the Arroyo La Manga and Cañada Ancha sections (Fig. 5).

Bioturbated wackestones $\left(\mathrm{W}_{\mathrm{b}} \mathrm{b}\right)$ are similar to those of previous facies association, but is appears in lower abundance. Laminated 
wackestones $\left(W_{\mathrm{b}}\right)$ are have sharp contacts, and tops are usually bioturbated. Bioclasts are scattered and none of these elements are in life position. They include ammonites, aptychi, infaunal bivalves, serpulids, and brachiopods. In the Tithonian interval microfossils includes ostracods, bentonic foraminifera (Epistomina, Lenticulina and Textularia), Saccocoma and calcisphaeres (Fig. 8D). In the Berriasian-Valanginian interval become more common the association of ophiuroids, dasycladacean algae, Epistomina and ostracods (Fig. 8E).

Marls (Mrb, Mrh) are well laminated. Bioclastic marls contain some thin-shelled oyster, disarticulated infaunal bivalves, serpulids, and fish scales. Thin sections of concretions contained therein show the same textural characteristics of laminated packstones or wackestones. Organ-ic matter content is high, reaching up 2 to $4 \%$. Bioclastic rudstones/ floatstones $(R F \mathrm{bm})$ consists of massive, normal graded multi-event concentrations or inverse graded single concentrations. Bases are usual-ly erosive, but bed tops are sharp or transitional. Valves show chaotic distribution, imbrication, convex-up disposition, and development of stacking and nets, and are usually perpendicular to the stratification.
Laminated packstones $\left(P_{\mathrm{pih}}\right)$ are have sharp bases. They are dominat-ed by peloids or by micritic intraclastos, which range from fine to medium sand size. Fossils include ammonites, articulated and disarticulated bivalves, gastropods, phosphatized gastropod steinkerns, which are chaotically distributed.

Lapillite deposits are massive or graded (Lm, $\mathrm{Lg}$ ), with sharp and pla-nar bases. They contain coarse sand to granule size pumiceous fragments, and calcareous algae in minor proportions.

Bioturbation can occur in bioclastic floatstones/rudstones, bioturbated wackestones and lapillites, as exhumed galleries of Thalassinoides with passive filling. In contrast, laminated wackestone beds are usually bioturbated by Diplocraterion, Rhizocorallium and Thalassinoides.

\subsubsection{Interpretation}

As in facies association 2, bioturbated wackestones $\left(W_{\mathrm{bb}}\right)$, laminated packstones $(P$ pih $)$, and bioclastic marls $(\mathrm{Mrb})$ indicated deposition after reworking of seafloor by action of storm waves (Schieber and Southard, 2009; Schieber et al., 2010). In contrast, laminated wackestones ( $W_{\mathrm{b} h}$ )
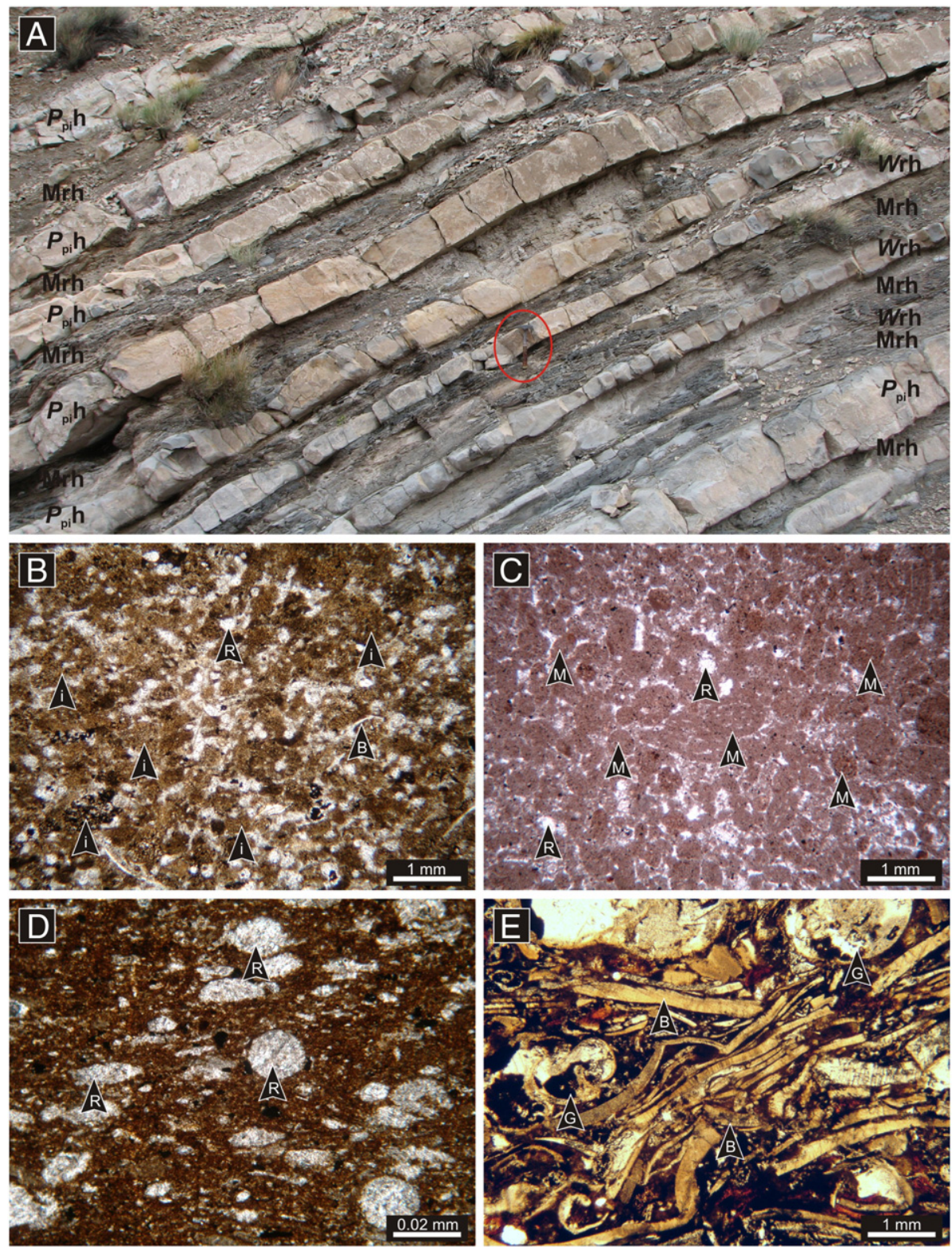

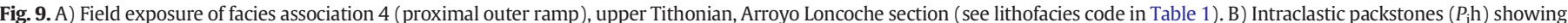

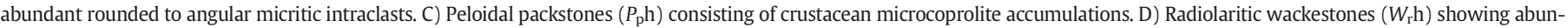

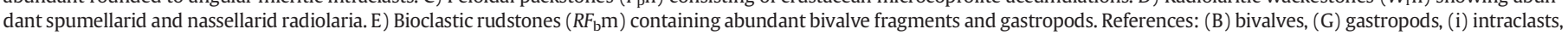
(M) crustacean microcoprolites (Palaxius caracuraensis Kietzmann), (R) radiolarians. 

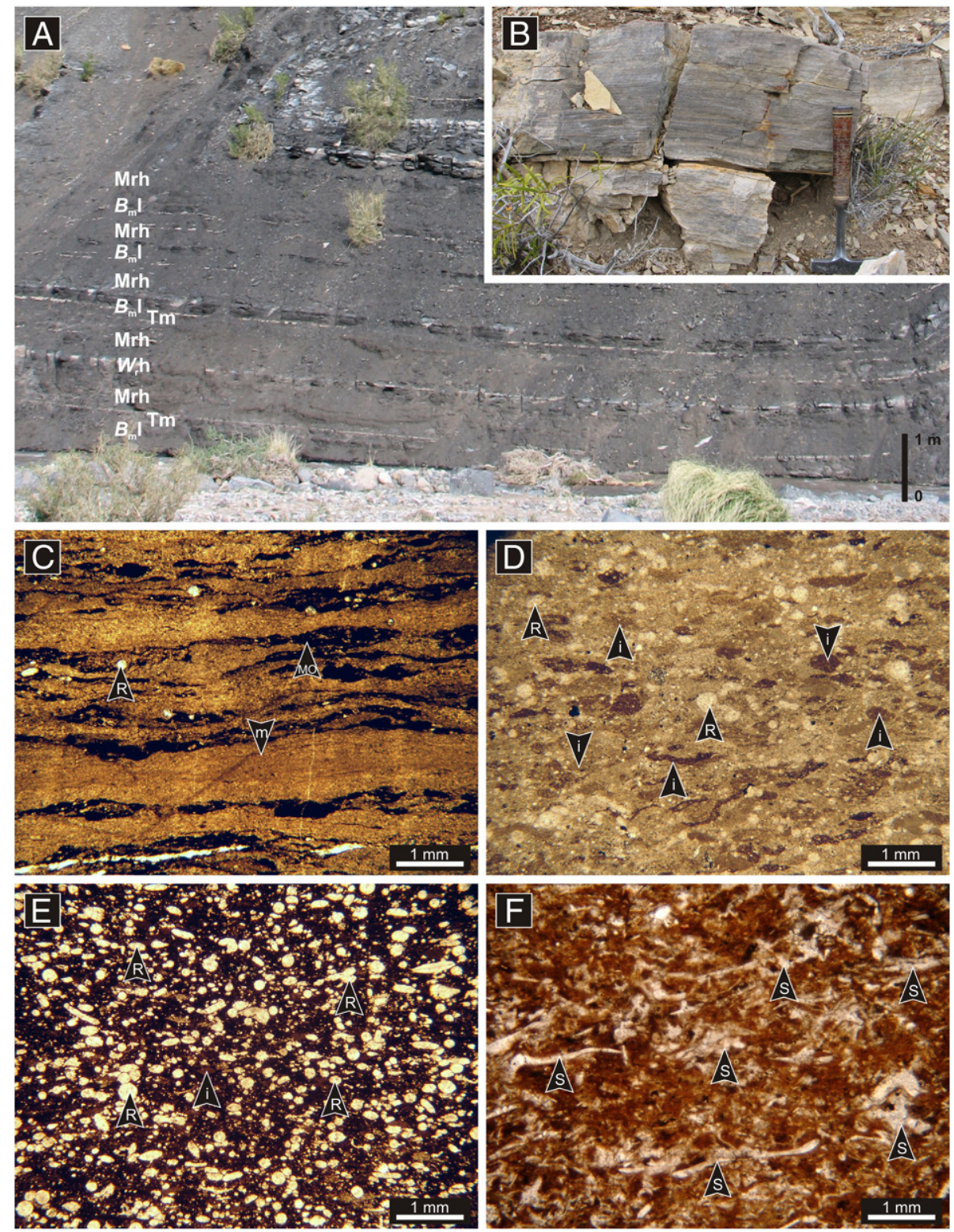

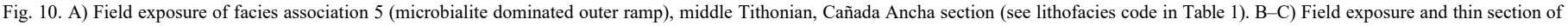

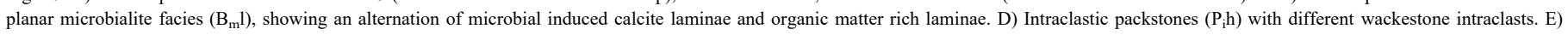

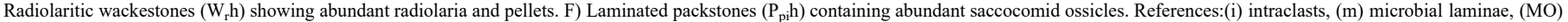
organic matter, $(\mathrm{R})$ radiolarians, $(\mathrm{S})$ sacoccomid microcrinoid ossicles.

and laminated marls (Mrh) represent a mixture of sedimentary processes including deposition by settling of fine grained suspended material (carbonate mud, radiolarians, calcisphaeres), during fair-weather periods, as well as sedimentary particles put in suspension during storm events. In fact, taphonomic features, along with exhumed Thalassinoides galleries with passive infilling, the absence of fauna in life position and the presence of trace fossils seeking a balance with the sediment-water boundary suggest reworking by storm-wave action.

The association of Thalassinoides, Diplocraterium and Rhizocoralliun is indicative of the Skolithos ichnofacies, which suggests colonization of storm beds by a community of opportunistic organisms in a post-event, highstress, physically controlled environment (Pemberton et al., 1992). Trace fossils indicate alternating energy regimes and a relatively well oxygenated substrate.

Massive and inverse graded lapillite deposits are probably deposited from floating rafts of air fall pumice originated in the Andean volcanic arc, whereas that normal graded lapillite were probably deposited from low density turbidites (e.g. Whitham, 1993).

Facies association 3 is interpreted as deposited in a moderate welloxygenated bioclastic middle ramp to proximal outer ramp setting, immediately below the storm-wave base. High organic matter content in marls suggests that oxygenation conditions were probably not constant, being occasionally dysoxic.

\subsection{Facies association 4 : proximal outer ramp}

\subsubsection{Description}

Low energy facies are represented in facies association 4 is by radiolaritic laminated wackestones $\left(\mathrm{W}_{\mathrm{r}} \mathrm{h}\right)$ and laminated marls (Mrh), rhythmically interbedded with peloidal and intraclastic laminated packstones $\left(\mathrm{P}_{\mathrm{pi}} \mathrm{h}\right)$ and thin graded bioclastic rudstones/floatstones $\left(\mathrm{RF}_{\mathrm{b}} \mathrm{m}\right)$, which represents high energy facies (Fig. 9), Subordinated 

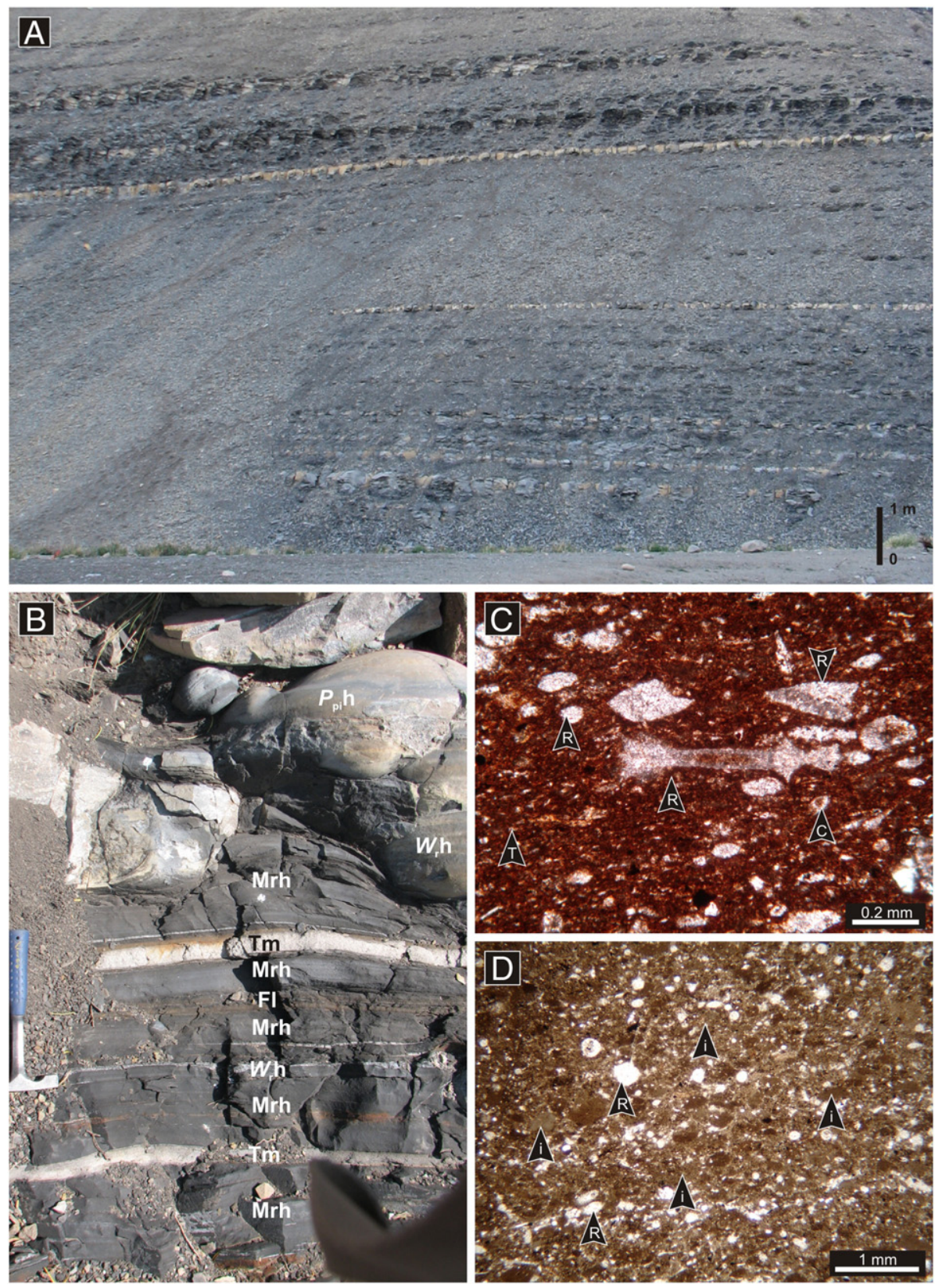

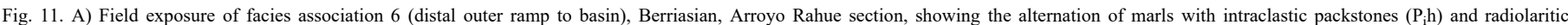

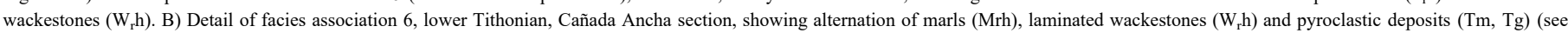

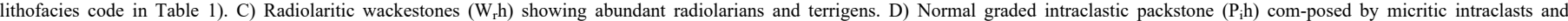
radiolarians. References: (C) calpionellids, (i) intraclasts, (R) radiolarians, (T) terrigens.

lapillite and tuff deposits are also present. The marl/limestone ratio is $\sim 3: 1$.

Facies association 4 is represented in all studied stratigraphic sections in Southern Mendoza (Fig. 5), and is characterized by marls with high organic matter content, reaching values of $5 \%$.

Radiolaritic wackestones $\left(\mathrm{W}_{\mathrm{r}} \mathrm{h}\right)$ are well laminated. They con-tain abundant radiolarians (Fig. 9D), including spumellarians and nassellarians with a ratio of 0.8 to 1 . Other bioclasts include ammonites, aptychi, and reworked infaunal bivalves, lingularids brachiopods, and occasionally serpulids.

Laminated packstones $\left(\mathrm{P}_{\mathrm{pi}} \mathrm{h}\right)$ are composed by well sorted, rounded to angular, fine to medium sand size micritic clasts, which correspond to radiolaritic wackestones or mudstones (Fig. 9B) or by crustacean microcoprolite accumulations (Fig. 9B). Fossils contained in the beds include reworked infaunal bivalves, serpulids, lingulid brachiopods, gastropods, echinoderms, and ammonites. These are filled by pellets, and distributed chaotically or parallel to the stratification. Bioturbation is rare, although at certain levels some Planolites, Palaeophycus and Thalassinoides tubes has been identified.

Thin graded bioclastic rudstones/floatstones $\left(\mathrm{RF}_{\mathrm{b}} \mathrm{m}\right)$ are single or multi event concentrations of bivalves, gastropods, ammonites and for-aminifers (Fig. 9E). Beds have sharp erosive bases, ranging in thickness from 2 to $10 \mathrm{~cm}$. The bivalves are disarticulated and highly fragmented, distribution of bioclasts is random or arranged relatively concordant to the bedding plane or stacked.

\subsubsection{Interpretation}

Fair-weather sedimentation is represented by marls and laminated radiolaritic wackestones, originated mostly from deposition by settling of fine grained suspended material, including planktonic microorganisms 

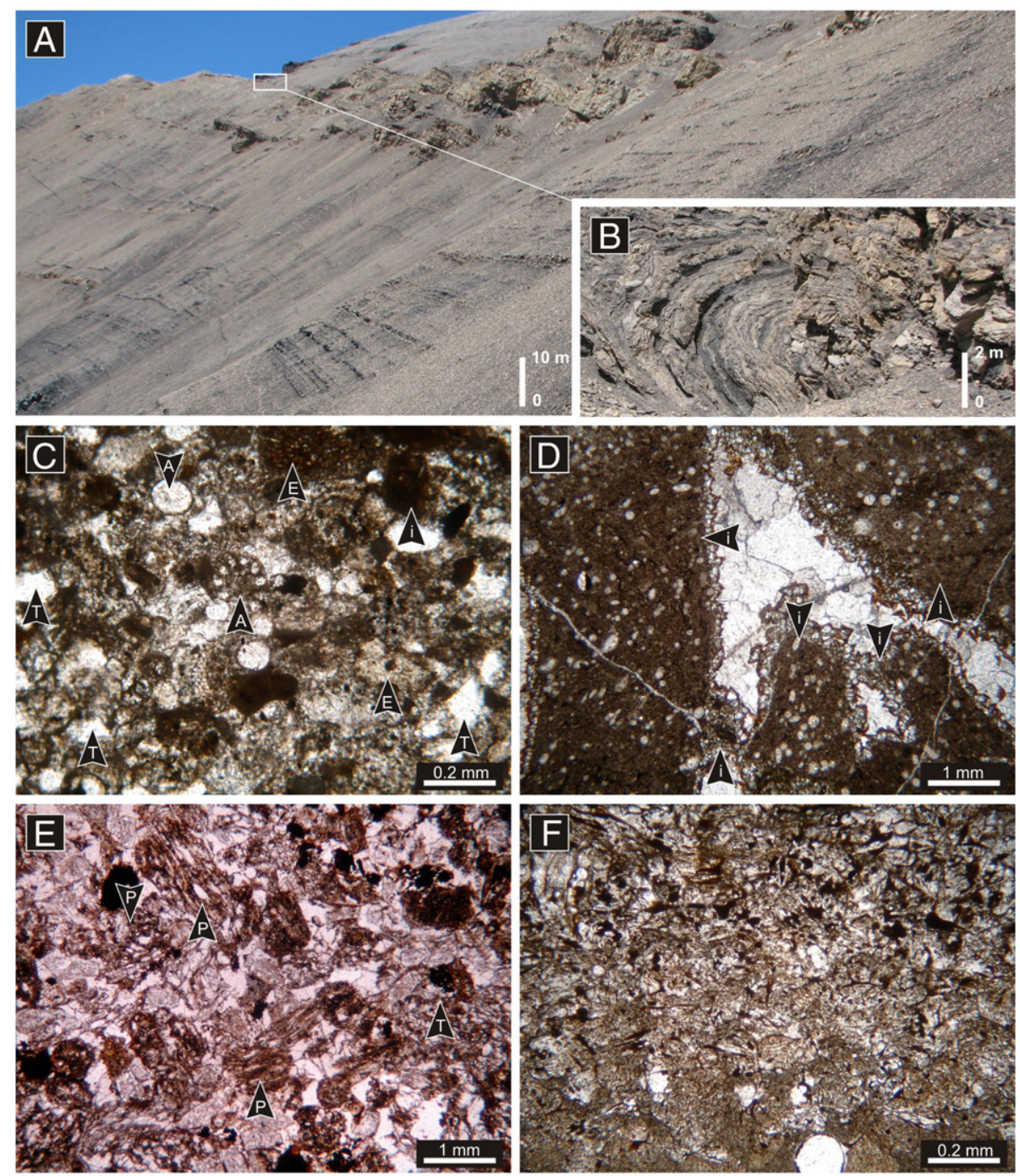

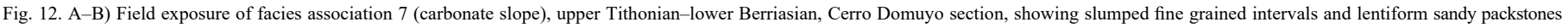

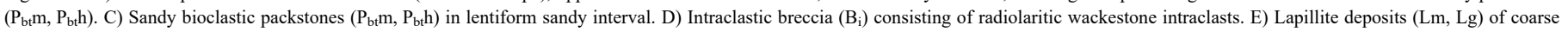

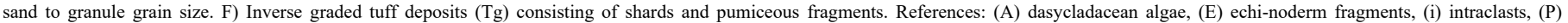
pumiceous fragments, $(\mathrm{T})$ terrigens.

and carbonate mud. Also, spumellarian and nassellarian ratio suggests distal open marine waters (see Kiessling, 1996). On the contrary, high en-ergy facies suggest deposition linked to storms. The abundance of peloids and micritic intraclasts, as well as disarticulated and fragmented fossils indicates that these sediments come from reworking of the seafloor dur-ing strong storms or storminduced return flows. In fact, intraclastic packstones show similar textures to the lenticular shale fabric describer by Schieber et al. (2010), which is associated with intermittent erosion processes and transport from bottom currents. Experimental observa-tions show that the erosion of muddy substrates tends to form intraclasts rather than resuspending muddy material, and these are transported by bed-load at relatively low velocities (Schieber and Southard, 2009; Schieber et al., 2010). Thin massive or graded bioclastic rudstones are sedimentary single or multi-event concentrations. Presence of dis-articulated and highly fragmented bivalves, with random arrangement, perpendicular orientation or stacking, suggests an origin as storm-generated turbidite-like flows (e.g. Monaco, 1992).

The presence of lucinid bivalves and epistominid foraminifera might suggest low-oxygen conditions, as they were probably chemosymbionts organisms (Sagasti and Ballent, 2002; Taylor and Glover, 2006). Plankton-ic and nektonic organisms, such as radiolarians, calcisphaeres and ammo-nite fragmocones also contributed to accumulation of sediments. Trace fossils are related to the Cruziana ichnofacies, characterizing low-energy environments, colonized by deposit- and suspension-feeders and also by mobile carnivores (Pemberton et al., 1992; MacEachern et al., 2008).

Facies association 4 is interpreted as deposited below the storm-wave base in a poorly-oxygenated bioclastic outer ramp setting.

\subsection{Facies association 5: microbialite dominated outer ramp}

\subsubsection{Description}

Facies association 5 is mainly represented by low energy fa-cies, including planar microbialites $\left(\mathrm{B}_{\mathrm{m}} 1\right)$, radiolaritic laminated wackestones $\left(\mathrm{W}_{\mathrm{r}} \mathrm{h}\right)$ and laminated marls $(\mathrm{Mrh})$, interbedded with laminated packstones $\left(\mathrm{P}_{\mathrm{pi}} \mathrm{h}\right)$ and subordinately tuff (Tm, Tg) deposits highly cemented by carbonates (Fig. 10A). The marl/limestone ratio is $\sim 3: 1$.

Facies association 5 is well represented in the lower part (lower and middle Tithonian) of the Cañada Ancha and Cerro Domuyo sections of the Vaca Muerta Formation (Fig. 5).

Planar microbialite beds $\left(\mathrm{B}_{\mathrm{m}} \mathrm{l}\right)$ consist of thinly laminated, fine-grained limestones, rich in organic matter, which are laterally continu-ous (Fig. 10BC). Some of these beds contain soft-sediment deformation structures, which are particularly significant in the basal microbial level 
of the Vaca Muerta Formation. Those structures include boudins of dif-ferent sizes and complexity, a variety of folds, normal dm-scale faults, subhorizontal detachment surfaces and other features, which are part of several larger-scale, complex slump structures (Martín-Chivelet et al., 2011). At the top of these beds, traces fossils such as Planolites, Chondrites, small forms of Thalassinoides, a n d Lumbricaria coprolites can occur. Also evidences of cryptobioturbation are found in microbialite laminae.

Bioclasts in radiolaritic laminated wackestones $\left(\mathrm{W}_{\mathrm{r}} \mathrm{h}\right)$ and laminated packstones $\left(\mathrm{P}_{\mathrm{pi}} \mathrm{h}\right)$ include reworked infaunal bivalves, gastropods, echinoderms, ammonites, and radiolarian and epistominid foraminifera. Laminated marls (Mrh) have high organic matter content, reaching values of $5 \%$.

Laminated packstones $\left(\mathrm{P}_{\mathrm{pi}} \mathrm{h}\right)$ are composed by well sorted, rounded to angular, fine to medium sand size micritic clasts (Fig. 10D). Fossils contained in the beds include reworked infaunal bivalves, gastropods, echinoderms, Saccocoma concentrations and ammonites. These are filled by pellets, and distributed chaotically or parallel to the stratification.

\subsubsection{Interpretation}

Original biocenosis in this subenvironment had reduced diversity, probably dominated by infaunal organisms, including crustaceans, shallow infaunal bivalves, and benthic foraminifera, whilst ammonites, radiolarian, and calpionellids, and calcisphaeres were present in the water column. Other skeletal components, such as gastropods, saccocomid microcrinoids, ophiuroids, and echinoids, are interpreted as allochthonous to parautocthonous.

Proliferation of microbial mats suggests a poorly oxygenated sub-strate and a low sedimentation rate. The submillimeter- to millimeter- scale lamination represents a combination of biologically influenced carbonate deposition, and settling of mud and planktonic organisms. Remobilization by bottom currents generated local accumulation of mi-crobial mats fragments, similar to those described by Schieber $(1998,1999)$ for deep-sea microbial mats. Presence of bioclastic material between microbial laminae probably indicates storm deposition. As suggested by Martin-Chivelet et al. (2011) deformation of the basal microbial level of the Vaca Muerta Formation could be associated with seismic activity at intermediate depths.

Radiolaritic wackestones and marls facies are mainly due to deposi-tion of mud, planktonic organisms, and particles transported during storms, while intraclastic packstones are interpreted as deposition of reworked intraclasts by bottom currents associated with storm events. Tuff deposits were probably originated in non-cohesive low density turbiditic currents.

Trace fossils could be related to the Cruziana ichnofacies, which indi-cates low-energy environments (Pemberton et al., 1992). Presence of Lumbricaria has been also cited in dysoxic environments (Savrda and Bottjer, 1986).

Facies association 5 is interpreted as deposited below the storm-wave base in a poorly-oxygenated outer ramp setting.

5.6. Facies association 6: distal outer ramp to basin

\subsubsection{Description}

Facies association 6 is dominated by dark gray to black well laminat-ed marls (Mrh). Subordinated appear laminated packstones $\left(\mathrm{P}_{\mathrm{i}} \mathrm{h}\right)$, ripplelaminated packstones $\left(\mathrm{P}_{\mathrm{p}} \mathrm{r}\right)$, radiolaritic wackestones $\left(\mathrm{W}_{\mathrm{r}} \mathrm{h}\right)$, and tuffs $(\mathrm{Tm}$, $\mathrm{Tg}$ ), similar to those of facies association 5 (Fig. 11A-B).

A Western margin

Eastern margin (Mendoza platform)

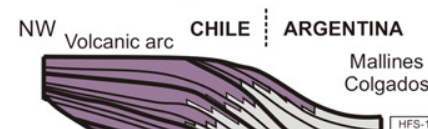

Mallines

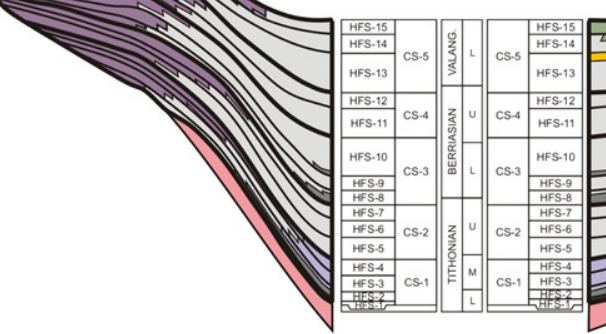

B

Western margin

Eastern margin (Mendoza platform)
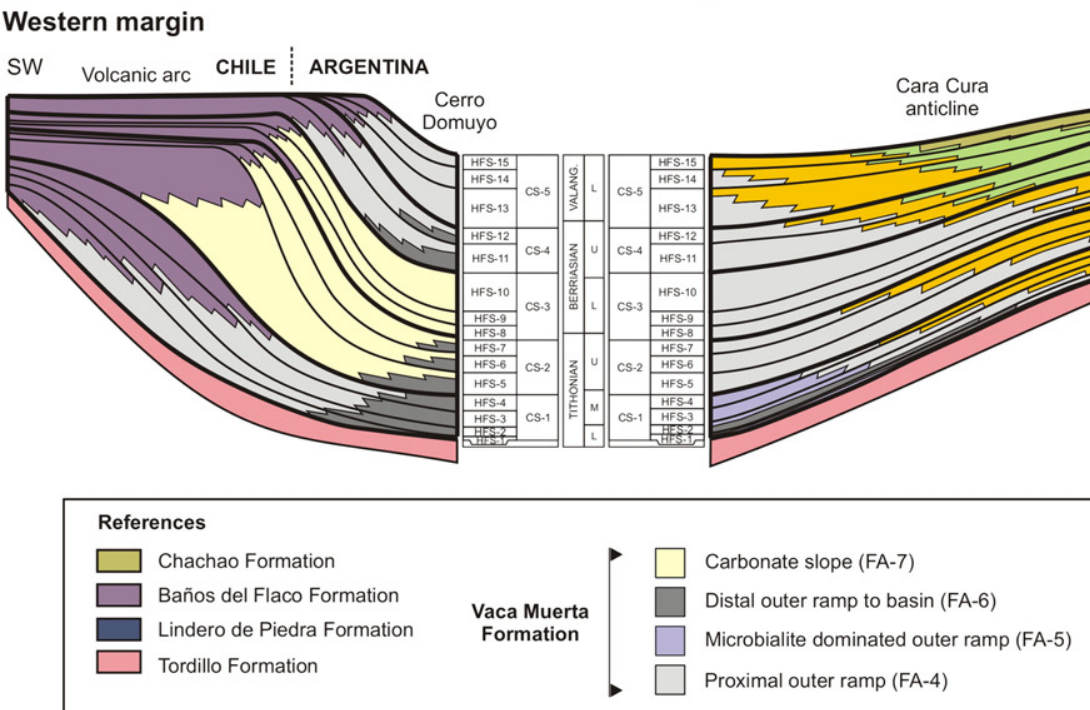

Bioclastic middle ramp to proximal outer ramp (FA-3)

HCS dominated middle ramp (FA-2)

Oyster autoparabiostrome dominated middle ramp (FA-1)

Baños del Flaco Formation

Lindero de Piedra Formation

Tordillo Formation

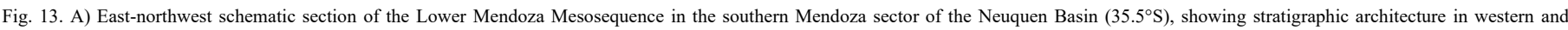

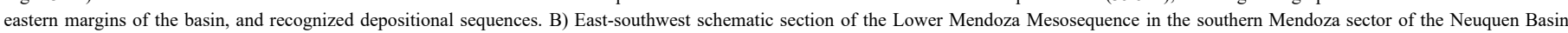
$\left(36.5^{\circ} \mathrm{S}\right)$, showing stratigraphic architecture in western and eastern margins of the basin, and recognized depositional sequences. 
The marl/limestone ratio is $\sim 6: 1$. This facies association is well repre-sented in the Cerro Domuyo section. It is characteristic in the basal part of the Vaca Muerta Formation (lower Tithonian to the lower part of the middle Tithonian), as well as in the upper Tithonian of the Arroyo La Manga and Cañada Ancha sections (Fig. 5). These intervals are the richest in organic matter, and therefore the main Vaca Muerta Forma-tion source levels (organic matter content reaches values of $7 \%$ ).

Bioclasts in laminated packstones $\left(\mathrm{P}_{\mathrm{i}} \mathrm{h}\right)$ and radiolaritic wackestones $\left(\mathrm{W}_{\mathrm{r}} \mathrm{h}\right)$ are mainly represented by thin-shelled oysters, abundant fish scales, and articulated fishes, reworked infaunal bivalves, gastropods, ammonites, radiolarian, and epistominid foraminifera, calpionellids and calcisphaeres. In the middle Tithonian interval, these beds are par-ticularly rich in vertebrate remains, including turtles, ichthyosaurs and crocodiles.

Packstones with ripple-lamination $\left(\mathrm{P}_{\mathrm{p}} \mathrm{r}\right)$ are tabular, centimeter thick, and have erosive bases and occasionally sole marks. Fine material is commonly accumulated between foreset laminae. In some cases hummocky-like cross stratified structures appears within them. Paleocurrent measures in this facies indicate southwest directions.

\subsubsection{Interpretation}

Sedimentation occurred mainly from suspension. However, presence of finegrained ripple laminated packstones, as well as bioclastic remains such as infaunal bivalves and echinoderm fragments, suggests shallow-water sediment input, probably associated with storm-generated turbid-ity flows.

The high organic matter content and absence of bottom-dwelling organisms suggest elevated organic productivity or good preservation, and sedimentation in a steady restricted marine environment with poorlyoxygenated bottom waters.

Tuffs were probably deposited from non-cohesive low density turbiditic currents, similar to those described by Whitham (1993) and Scasso (2001) from the Ameghino Formation of Antarctica.

Presence of benthic fauna is extremely limited, including epifaunal oysters and epistominid foraminifera. Spumellarian and nassellarian ratio in radiolaritic wackestones is about 0.8 to 1 , suggesting distal open marine waters, but values near 0.5 are also found, suggesting an oxygen-depleted environment (cf. Kiessling, 1996). Similar interpretation follows from the abundance of ammonites, microfossils, and vertebrate remains, indicating an anoxic to dysoxic environment.

Facies association 6 is interpreted as deposited below the storm-wave base in a poorly-oxygenated distal outer ramp to basin setting.

\subsection{Facies association 7: carbonate slope}

\subsubsection{Description}

Facies association 7 is composed by slumped fine grained sandy bioclastic packstones $\left(\mathrm{P}_{\mathrm{pt}} \mathrm{m}, \mathrm{P}_{\mathrm{pt}} \mathrm{h}\right)$, lapillites ( $\left.\mathrm{Lm}, \mathrm{Lg}\right)$, tuffs $(\mathrm{Tg})$, intraclastic breccias $\left(\mathrm{B}_{\mathrm{i}}\right)$, and laminated marls $(\mathrm{Mrh})$ (Fig. 12A-B). This facies association is only recognized in the Cerro Domuyo section, and occurs in an interval called Huncal Member (Leanza et al., 2003). It is composed of slumped lentiform bodies of massive to poorly laminated fine grained sandy bioclastic packstones, developed between two slumped complexes. The marl/limestone ratio is $\sim 1: 3$.

Fine grained sandy bioclastic packstones $\left(\mathrm{P}_{\mathrm{pt}} \mathrm{m}, \mathrm{P}_{\mathrm{pt}} \mathrm{h}\right)$ forms coarsen-ing upward lentiform bodies of 5 to $15 \mathrm{~m}$ high and about $1000 \mathrm{~m}$ length. Particles include echinoderm fragments, dasycladacean algae, infaunal bivalves, oolite grainstone intraclasts, and terrigens (Fig. 12C).

Slumps are conspicuous and characteristics structures of this facies association. They have thickness of several meters $(\sim 1-10 \mathrm{~m})$ and verges to the northeast (Kietzmann and Vennari, 2013), contrasting with other paleocurrent measures in the Vaca Muerta Formation, which have westward paleodirections.

Intraclastic breccias $\left(\mathrm{B}_{\mathrm{i}}\right)$ are mantiform clast-supported monomictic beccias. Contacts are sharp and planes. Clasts are micritic (radiolaritic wackestones and mudstones) pebble sized, and angular to subangular
(Fig. 12D). Thickness of beds increases westward from centimeters to decimeters along about $3 \mathrm{~km}$.

Lapillite deposits are very abundant in this association. They are massive $(\mathrm{Lm})$ or graded $(\mathrm{Lg})$, and consist of abundant pumiceous frag-ments, fine sandsize micritic intraclasts, dasycladacean algae, crusta-cean microcoprolites, and subordinately silt size terrigens (Fig. 12E).

Tuff deposits (Tg) are tabular, with sharp planar or slightly erosive basal contacts. They are composed of abundant glass shards and pumi-ceous fragments in inverse graded layers of 2 to $5 \mathrm{~mm}$ thick (Fig. 12F).

Fossil content in laminated marls (Mrh) is scarce and includes belemnites, ammonites, trunks and branches, and fish scales.

\subsubsection{Interpretation}

Lapillite and tuff deposits are very abundant in this association, sug-gesting sedimentation in proximity of the Andean volcanic arc. These deposits were probably deposited from rafts of floating pumice, ash falls and/or low density turbidites (cf. Whitham, 1993). The northeast vergence of landslides indicates the proximity of the Cerro Domuyo section to the western margin of the Neuquén Basin during the Late Jurassic, represented by the volcanic arc.

The massive to poorly laminated lentiform bodies composed by fine grained sandy bioclastic packstones and associated with slumped inter-vals, are interpreted as a grain-dominated slope apron deposited at the t o e o f the slope ( Playton et al., 2010). Presence of echinoderm fragments, dasycladacean algae, oolite grainstone intraclasts, and terrigenous mate-rials, suggests transport from shallower and protected areas.

Grain-supported intraclastic breccias are interpreted as non-cohesive debris-flow deposits, as suggested by their non-erosive bases and lateral increment in thickness. Clast composition suggests that the break of slope was in distal sectors of the depositional system.

Facies association 7 is interpreted as accretionary slope deposits linked probably with a carbonate open shelf or a distally steepened ramp system.

\subsection{Sedimentary environment}

During early Tithonian to early Valanginian the Neuquén Basin would have behaved as a partially closed basin, bounded on the west by a volcanic island arc and connected with the Pacific Ocean by narrow marine passages (Legarreta and Uliana, 1991; Howell et al., 2005). This configuration allowed the existence of low energy and relatively shallow marine ramps with development of carbonate and mixed carbonate-siliciclastic depositional systems.

Carbonate platform geometry was related to hydrodynamic setting and biological characteristics. In fact, ramp geometries are seen as the products of decreased differentiation of depth-dependent production rates, depth-enhanced carbonate production, and/or strong offshore transport, as well as the lack of frame-building organisms capable of building steep platform margins (Pomar and Kendal, 2008). The last two factors were most probably those controlling facies distribution of the Vaca Muerta carbonate ramp system.

On the eastern margin of the basin a homoclinal carbonate ramp sys-tem was developed (Vaca Muerta-Chachao carbonate ramp system), while between volcanic arc in the western margin, a series of carbonate shallow areas generated a distally steepened ramp system (Vaca Muerta-Baños del Flaco carbonate ramp system), which shows its maximum expression with the Huncal Member towards the Neuquen embayment (Fig. 13).

The Vaca Muerta-Chachao carbonate ramp has a shallow facies belt dominated by sedimentologic recliner-oyster accumulations, among which are intercalated isolated branching coral patches and biodetritic mud mounds (Legarreta and Kozlowski, 1981; Palma et al., 2000). This facies belt includes subtidal inner ramp to middle ramp deposits of the Chachao Formation, which grades basinward to middle ramp oyster auto-parabiostromes (FA-1), which were reworked and transported forming bioclastic middle to outer ramp deposits (FA-3). 


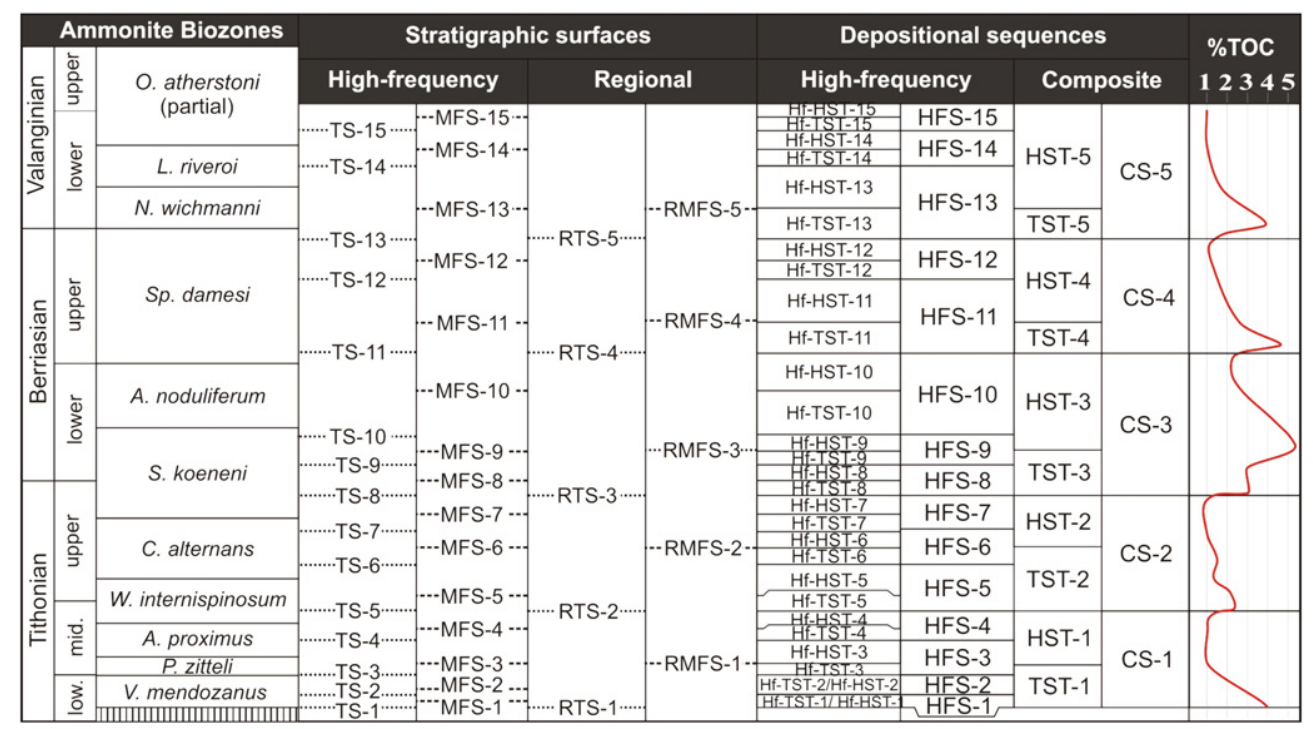

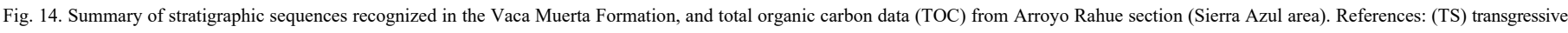

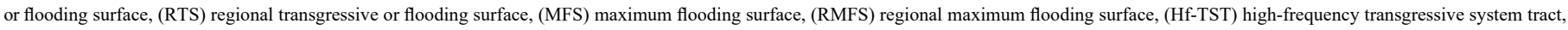
(Hf-HST) high-frequency highstand system tract, (TST) transgressive system tract, (HST) highstand system tract, (HFS) high-frequency depositional sequence,(CS) composite depositional sequence.

During fair-weather stages, these shallow areas were dominated by low energy conditions, allowing proliferation of recliner benthic organ-isms, such as oysters and serpulids, in a sedimentary environment dom-inated by sedimentation of carbonate mud. In contrast, storm events caused reworking and transport of organisms to distal areas of the car-bonate ramp. In fact, these kind of muddy-substrate recliner-oyster reefs originate under low to moderate sedimentation rates (Seilacher et at., 1985; Machalski, 1989). Our data indicate an early Valanginian sedimentation rate between 8 and $30 \mathrm{~m} / \mathrm{Ma}$, and taphonomic evidence indicates that oyster accumulations were reworked during high energy events, showing displacement of life-position, disarticulation and even fragmentation. Actually, a continuous low energy sedimentation with intermittent high energy episodes of reworking is probably the most likely mechanism responsible for the formation of this facies belt.

In unfavorable areas for the generation of muddy-substrate recliner-oyster reefs, the ramp was dominated by settling of mud and prolifera-tion of benthic organisms such as crustaceans, gastropods, ophiuroids, saccocomid microcrinoids, rotularid serpulids, as well as infaunal bivalves and brachiopods. Presence of transported, but moderately well preserved, green algae and sponges spicules, suggest low energy conditions and shallow water. Particularly, presence of callianassid crustaceans must have been important, given the abundance of fecal pellets produced by these organisms (Kietzmann and Palma, 2010a,b; Kietzmann et al., 2010b). Probably, the sea floor had an irregular topogra-phy, similar to the present day Bahamas platform, with conical mounds connected with extensive horizontal galleries systems (Warme, 1967; Wanless et al., 1988).

During storms, these conical mounds were truncated and flattened by wave activity, forming hummocky-cross stratified beds, and thin bioclastic deposits. Pellets were transported to the outer shelf, where they were concentrated generating pelletoidal muds (Wanless, 1979).

These shallow areas of the carbonate ramp are represented by facies association 2. Similar examples in the sedimentary record are the Betic Middle Jurassic carbonate ramp deposits of Spain (Molina et al., 1997), the UmbriaMarche Middle Jurassic of Italy (Monaco, 1992), and some Paleogene deposits of southwestern Iran (Mohseni and Al-Aasm, 2004), among others.

A second facies belt is represented by facies associations 4,5 and 6 , which represent the distal part of the carbonate ramp, extending from outer ramp to basin. In this sector the carbonate ramp was dominated by settling of mud and planktonic organisms, as well as pellets and bioclasts transported during storms. Proliferation of benthic organisms was much more restricted than in middle ramp. In moderate to well oxygenated sectors the substrate was colonized by shallow infaunal bi-valves, recliner-flatoysters and benthic foraminifera, and callianassids, which contributed to the pelletization of the seafloor.

With exception of some localities where sedimentation was proba-bly controlled by preexisting topographic highs (as in Mallín Redondo section, southern Sierra Azul), the sedimentation rate was of 25 to $35 \mathrm{~m} / \mathrm{Ma}$. During Tithonian times low sedimentation rates favored the proliferation of microbial mats in some areas like Cañada Ancha and Cerro Domuyo.

Presence of storm deposits between microbial laminae indicates mod-erate energy hydrodynamic conditions were of. As suggested by Mata and Bottjer (2009), development of microbial horizons would be favored under transgressive conditions due to a significant decrease in sedimen-tation rate, and microbial mats could colonize the seabed below the fair-weather wave zone (Schlager, 2005; Álvaro and Clausen, 2006).

The third facies belt is represented by facies association 7, which is interpreted as slope deposits linked probably with an open carbonate shelf or a distally steepened ramp system. The intercalation of slumped deposits and gravity flows with east-northeast paleodirections, indi-cates establishment of a slope in the western margin of the basin, relat-ed to a shallow protected environment developed within the Andean volcanic arc. In the south of the basin, similar facies are represented by the Picún Leufú Formation, which is interpreted as originated in shallow protected areas, with lagoons and oolitic bars (Armella et al., 2007). In Chilean territory, backarc sequences equivalent to the Mendoza Group, i.e. the Lo Valdés and Baños del Flaco Formations, are interpreted as originated in a restricted subtidal environment limited by oolitic bar-riers (Moreno and Pino, 2002).

\section{Sequence stratigraphy}

In this paper we present a new sequence stratigraphic framework for the Vaca Muerta Formation, based in the intensive stratigraphic work performed by the authors in southern Mendoza during the last years.

Sequences stratigraphic units were defined in this paper using the recognition of flooding or transgressive surfaces (TS), which are the best developed and less ambiguous stratigraphic surfaces for the 
positions of the analyzed sedimentary environment. System tracts are defined by stacking pattern and facies tendency.

Based on this analysis, two hierarchies of depositional sequences are recognized, used here as composite depositional sequences (CSs) for highrank sequences, and high-frequency depositional sequences (HFSs) for those of small scale (F i g s.5,13). Because of its average dura-tion, high-rank sequences are considered to be equivalent to third order sequences, while lowrank sequences are considered as fourth order sequences (e.g., Kerans and Tinker, 1997).

\subsection{First composite depositional sequences (CS-1)}

Composite depositional sequences CS-1 starts with the transgressive surface TS-1, which is an important regional surface (RTS-1) where the late Kimmeridgian continental/transitional deposits of the Tordillo For-mation are overlapped by microbialite dominated outer ramp deposits of the Vaca Muerta Formation. This basal surface coincides with the basal microbialite level of the Vaca Muerta Formation, which contains ammonites from the lower Tithonian V. mendozanus Biozone (Fig. 5), and has been named informally as Las Amarillas level by Martín-Chivelet et al. (2011). The upper limit is determined by the transgres-sive surface TS-5, which is another surface of regional value recognized throughout the basin (RTS-2) and is located within the uppermost middle Tithonian Windhauseniceras internispinosum Biozone (Fig. 14).

In the eastern margin the transgressive system tract (TST-1) is clear-ly retrograding, beginning in almost all stratigraphic sections with microbialite dominated outer ramp deposits (FA-5), grading into prox-imal outer ramp deposits (FA-4), and then to the distal outer ramp deposits (FA-6), representing a maximum flooding zone (RMFZ-1) located within the lowermost middle Tithonian Pseudolissoceras zitteli Biozone. TOC values in the TST-1 reach $4 \%$ (Fig. 14).

The highstand system tract (HST-1) is defin e $\mathrm{d}$ b y a $\mathrm{n}$ e $\mathrm{t} \mathrm{p} \mathrm{r}$ o g radational strata arrangement characterized in distal positions of the carbonate ramp by the progradation of microbialite dominated outer ramp deposits (FA-5) and proximal outer ramp deposits (FA-4), and proximal outer ramp facies (FA-4), bioclastic middle ramp to proximal outer ramp (FA-3), HCS dominated middle ramp facies (FA-2), and oys-ter autoparabiostrome dominated middle ramp facies (FA-1) (Figs. 5, 13). TOC values in the HST-1 decrease to $1 \%$.

In the western margin facies remain homogeneous, recognizing the progradational pattern by an increase in carbonate content (Figs. 5, 13). The first composite sequence contains four high frequency sequences (HFS-1 to 4), whose temporal distribution can be seen in Fig. 14.

\subsection{Second composite depositional sequences (CS-2)}

Composite depositional sequences CS-2 begins with the transgressive surface TS-5 (lower part of the middle Tithonian W. internispinosum Biozone). The upper limit is determined by the transgressive surface TS-8 (RTS-3), which is located within the uppermost upper Tithonian Substeueroceras koeneni Biozone.

The transgressive system tract (TST-2) is recognized in the eastern margin by a facies deepening, from middle ramp deposits (FA-1, 2 or 3) to proximal outer ramp deposits (FA-4) (Fig. 13). In the western margin the TST-2 is represented by the progradation of carbonate slope deposits (FA-7) related with the generation of a steep slope due to the increase in accommodation space (Kietzmann and Vennari, 2013). TOC values in the TST-2 reach 2.4\% (Fig. 14).

The highstand system tract HST-2 in the eastern margin consists of a net progradational strata arrangement from proximal outer ramp de-posits (FA-4) to HCS dominated middle ramp deposits (FA-2) in Sierra Azul and Sierra de la Cara Cura anticlines, from proximal outer ramp (FA-4) to bioclastic middle ramp to outer ramp deposits (FA-3) in the Malargüe Anticline, and from proximal outer ramp (FA-4) to HCS dominated middle ramp deposits (FA2) in the Atuel depocenter. In the western margin HST-2 is represented by carbonate slope deposits (FA-7) (Figs. 5, 13). TOC values in the HST-2 decrease to $0.8 \%$ (Fig. 14).

Composite depositional sequences CS-2 contains three highfrequency sequences (HFS-5 to 7), whose temporal distribution and facies can be seen in Fig. 14.

\subsection{Third composite depositional sequences (CS-3)}

Composite sequence CS-3 begins with the transgressive surface TS- 8 during late Tithonian (S. koeneni Biozone), and ends with transgressive surface TS-11 (RTS-4) in the early late Berriasian (lower part of the Spiticeras damesi Biozone) with the progradation of bioclastic middle ramp facies (Fig. $5)$.

The transgressive system tract (TST-3) is recognized in the eastern margin by a facies deepening, from middle ramp deposits (FA-2 or 3 ) to proximal outer ramp deposits (FA-4) in most of the studied sections or to distal outer ramp to basin deposits (FA-6) in the Atuel depocenter (Figs. 5, 13). TOC values in the TST-3 reach 5 to $7 \%$ (Fig. 14).

The highstand system tract HST-2 in the eastern margin consists of a progradational strata arrangement from proximal outer ramp deposits (FA-4) to HCS dominated middle ramp deposits (FA-2) in Sierra Azul and Sierra de la Cara Cura anticlines, and proximal outer ramp (FA-4) or bioclastic middle ramp to outer ramp deposits (FA-3) in the Malargüe Anticline (Figs. 5, 13). TOC values in the HST-3 decrease to $2 \%$ (Fig. 14).

In the western margin the composite sequence CS-3 is represented by carbonate slope deposits (FA-7), which coincides with the Huncal Member (Kietzmann and Vennari, 2013).

Composite sequence CS-3 contains three high-frequency sequences (HFS-8 to 10). Their temporal distribution and facies can be seen in Fig. 14.

\subsection{Fourth composite sequence (CS-4)}

Composite sequence CS-4 lies between transgressive surface TS-11 (RTS-4) and TS-13 (RTS-5) in the upper Berriasian (S. damesi Biozone, Figs. $5,14)$.

In the eastern margin the transgressive system tract (TST-4) consists of proximal outer ramp deposits (FA-4), while the highstand system tract (HST-4) shows the progradations of to bioclastic middle ramp-proximal outer ramp facies (FA-3), HCS dominated middle ramp facies (FA-2) and finally to oyster auto-parabiostrome dominated middle ramp facies (FA-1).

The western margin is dominated by proximal outer ramp facies (FA-4) which prograde over distal outer ramp to basin deposits (FA- 6). TOC values in the TST- 4 reach $4.6 \%$ and decrease in HST- 4 to $0.9 \%$ (Fig. 14).

Composite sequence CS-4 contains two high-frequency sequences (HFS-11 and 12; Fig. 14).

\subsection{Fifth composite sequence (CS-5)}

Composite sequence CS-5 begins with the transgressive surface TS- 13 in the uppermost part of the upper Berriasian (S. damesi Biozone), and ends in the lower Valanginian (lower part of the O. atherstoni Biozone) with the progradation of the shallow oysters-dominated de-posits of the Chachao Formation (Fig. 5). In the more distal positions, as the Bardas Blancas or the Arroyo Rahue sections, the lower part of the O. atherstoni Biozone is represented by facies of the Vaca Muerta Formation, and culminates with the regional transgressive surface, that marks the beginning of the Agrio Formation.

In the eastern margin the transgressive system tract (TST-5) consists of proximal outer ramp (FA-4) and bioclastic middle ramp-proximal outer ramp (FA-3) deposits, while the highstand system tract (HST-5) shows the progradations of to bioclastic middle ramp-proximal outer ramp facies (FA-3) or HCS dominated middle ramp facies (FA-2), and fi-nally oyster autoparabiostrome dominated middle ramp facies (FA-1) 
or oyster dominated facies of the Chachao Formation (Fig. 5). TOC values in the TST-5 reach $4 \%$ and decrease in HST-5 to $1 \%$ (Fig. 14).

The western margin is dominated by proximal outer ramp facies (FA-4), but in the Cerro Domuyo section HST-5 is not represented due to erosion.

Composite sequence CS-4 contains three high-frequency sequences (HFS-13 to 15)

\section{Discussion}

\subsection{Sedimentary environment}

The sedimentary environment of the Vaca Muerta Formation was traditionally interpreted as basinal to slope deposits, based on seismic interpretations, as well as outcrops and well data in the Neuquén em-bayment (Leanza, 1973; Leanza et al., 1977; Mitchum and Uliana, 1985; Legarreta and Uliana, 1991, 1996). Similar interpretations were performed for the Mendoza platform (Legarreta et al., 1981; Mitchum and Uliana, 1985; Legarreta and Uliana, 1991, 1996).

The conception that the Vaca Muerta Formation in the Neuquén embayment represents basin-slope facies is due to the sigmoidal geometry of clinoforms on seismic sections, although detailed sedimentological studies were never performed. According to Mitchum and Uliana (1985) data, maximum inclination of clinoform slopes does not exceed $0.6^{\circ}$ during the Tithonian-Berriasian. In fact, depositional systems dom-inated by production of mud-size sediment in the shallow-water zone have a minimum capacity to fill the accommodation of a shallow-water shelf. Storms erode and suspend this fine material, so it is easily shed downshelf and the angle of repose is very low, resulting in a homoclinal ramp depositional profile (Pomar and Kendall, 2008).

Detailed facies analysis presented in this paper, and previous works (Kietzmann et al., 2008, 2011a; Kietzmann and Palma, 2009a, 2011) indicate high lateral and vertical facies variability. The Vaca Muerta Formation in the southern Mendoza sector of the Neuquén Basin is the result of two systems: the westward progradations of a homoclinal ramp and the outermost part of a distally steepened ramp, whose shal-low facies were developed in the present Chilean territory to the west.

Early sequential stratigraphic studies on the Tithonian-Valanginian successions of the Neuquén Basin were made by Mombrú et al.(1978), who studied the Chachao Formation deposits using a reef-rimmed shelf model, recognizing three episodes of flooding, culminat-ing with dolomitization and subaerial exposure phenomena. This model was subsequently abandoned by Legarreta and Kozlowski (1981) and Mitchum and Uliana (1985), who interpreted the Chachao Formation as an alternation between ramp and platform geometries with offshore organic banks development at the break of slope. Finally, detailed microfacial and taphonomic studies carried out by Palma (1996) and Palma and Lanés (2001) concluded that deposits of the Chachao Formation are related to a carbonate ramp geometry.

The detailed data presented in this work shows that the deposition of the Vaca Muerta Formation occurred in shallower conditions than previously accepted, in the context of a low-gradient carbonate ramp rather than in an basin-slope environment. This interpretation coincide the idea that rich organic matter systems occurred mostly in shallow environments rather than in deep-water systems.

\subsection{Sequence stratigraphy}

Seismic sequences of Mitchum and Uliana (1985) were made with lowquality seismic data, but since then no regional studies were per-formed. These authors defined nine depositional sequences (A to I) for the lower Tithonianlower Valanginian interval (Vaca Muerta and Chachao Formations): Four tithonian sequences (A to D), two berriasian sequences ( $E$ to $F$ ) and three lower valanginian sequences ( $\mathrm{G}$ to $\mathrm{I})$. This set of depositional sequences were included by Legarreta and Gulisano (1989) within the Lower Mendoza Mesosequence $\left(\mathrm{Mi}_{1}\right.$ to $\left.\mathrm{Mi}_{9}\right)$, and assigned to depositional sequences defined by Haq et al. (1987, 1988)(see Fig. 2).

Sequence $\mathrm{Mi}_{1}$ of Legarreta and Gulisano (1989) include the Tordillo Formation (LST) and the basal part of the Vaca Muerta Formation (TST and HST), whereas the last depositional sequence recognized in the Chachao Formation was incorporated into the Middle Mendoza Mesosequence $\left(\mathrm{Mm}_{1}\right)$ by correlation with the Mulichinco Forma-tion, which is separated from the Vaca Muerta Formation by the intravalanginian unconformity (Stipanicic and Rodrigo, 1970; Gulisano et al., 1984).

The sequence stratigraphic framework presented in this paper include five composite depositional sequences and fifteen high-frequency depo-sitional sequences, which are supported by detailed sedimentological and biostratigraphical data. As no field evidence of subaerial exposure are available for the Vaca Muerta Formation that could help to recognize sequence boundaries and/or their correlative conformities, flooding surfaces have proven to be useful for stratigraphic studies. Thus, recogniz-ing the composite depositional sequences, as done in the present work, can be an important subsurface tool for correlation, since flooding sur-faces can be detected by gamma rays, and probably could be detected with modern seismic resolution. In fact, the five major progradations (composite sequences) are outlined in the work of Legarreta and Kozlowski (1981), Legarreta et al. (1981) and Legarreta and Gulisano (1989), and are easily recognizable in the field (Spalletti et al., 2000; Kietzmann et al., 2008, 2011a; Kietzmann and Palma, 2009a, 2011).

Regarding the youngest sequences, we found no evidence of an intravalanginian unconformity within the Vaca Muerta Formation. This unconformity was probably tectonically induced, resulting in a basinward shift of proximal marine and continental facies belts (Gulisano et al., 1984; Vergani et al., 1995). But unlike Neuquén Prov-ince, where the continental deposits of the Mulichinco Formation directly overlap the Vaca Muerta and Quintuco Formations (Gulisano et al., 1984; Legarreta and Gulisano, 1989), in Southern Mendoza this intravalanginian unconformity is absent. Only in Sierra de la Cara Cura we recognized an intravalanginian unconformity between the Chachao and Mulichinco Formations. This unconformity, however, is not present north of this area, where the Vaca Muerta Formation grades transition-ally to the Agrio Formation, as shown in the Arroyo Rahue and Cañada Ancha sections.

\subsection{Relevance for the Vaca Muerta shale-gas/oil system}

A correct interpretation of the sedimentary environment and the sequence stratigraphic framework of the Vaca Muerta Formation is necessary to understand the Vaca Muerta shale system. Sedimentary en-vironment and diagenesis can control the micro- and/or cryptoporosity type (Slatt and O'Brien, 2011; Loucks et al., 2012), but organic matter distribution could be also controlled by facies changes, fluctuations in productivity/fertility or in sedimentation rate, among other factors (e.g. Passey et al., 2010; Graham, 2012).

The obtained TOC curve shows five intervals with a decreasing trend (Fig. 14), which correlates with the five composite depositional sequences. Each interval starts with a significant increase in TOC values of 4 to $7 \%$, coinciding with the transgressive system tract, and then decreased to 0.8 to $1 \%$ coinciding with the highstand system tract.

In composite depositional sequences CS-2 and CS-3 high frequency variations are observed, but more data are needed to ensure that high frequency sequences also exert a control on the total organic content.

These data also show a significant difference with TOC curves from the southern sector of the basin (Urien and Zambrano, 1994; Villar et al., 1998; Cruz et al., 2002), which shows high TOC values (8-12\%) in basal part of the Vaca Muerta Formation (V. mendozanus and P. zitteli Biozones), and then decrease significantly to the Picún Leufú and Quintuco Formations.

Organic matter data from Arroyo Rahue section were chosen as representative of the Vaca Muerta Formation in southern Mendoza 
(Fig. 14), because this locality is characterized by a reduced facies vari-ability (mainly facies association 4: bioclastic outer ramp),and therefore it can be inferred a relationship between the organic matter content and see-level fluctuations within a sequence stratigraphic context.

Carbonate ramps responds quickly to changes in sea level (Burchette and Wright, 1992; Handford and Loucks, 1993; Tucker et al., 1993). Transgressive system tracts may become the most important part of a carbonate ramp sequence, due to its low topographic gradient. The rapid flooding of the ramp generates a migration of the carbonate production area to shallow ramp, whereas in the outer ramp the sedimentation rate is significantly reduced, and the environment stays under reduced oxygenation conditions, allowing a significant accumu-lation of organic matter (e.g. Hardie, 1986; Emery and Myers, 1996). In contrast, during regressive stage carbonate ramps prograde increas-ing erosion and sediment exportation to distal parts of the environment, diluting and oxidizing organic matter (e.g. Burchette and Wright, 1992; Bádenas et al., 2005).

Therefore the sedimentary evolution of the Vaca Muerta Formation deposits and sequence stratigraphic model should be established to locate possible intervals for the exploration of this exceptional uncon-ventional reservoir of the Neuquén Basin.

\section{Conclusions}

The Vaca Muerta Formation in the Southern Mendoza sector of the Neuquén Basin is interpreted as the westward progradation of a homoclinal ramp located on the eastern margin of the basin, while on the western margin represents the outermost part of a distally steeped ramp, whose shallow facies were developed in the present Chilean territory.

Based on the identification of flooding surfaces two hierarchies of transgressive-regressive cycles are recognized: five composite deposi-tional sequences, and fifteen high frequency depositional sequences, which together show a regressive trend.

First composite depositional sequence starts in the lower Tithonian (V. mendozanus Biozone) with a regional transgressive surface, which overlap late Kimmeridgian continental/transitional deposits by microbialite dominated outer ramp deposits, and ends in the upper-most middle Tithonian (W. internispinosum Biozone).

Second composite depositional sequence develops between the mid-dle Tithonian and the uppermost upper Tithonian (W. internispinosum to S. koeneni Biozones), while composite depositional sequence include upper Tithonian to upper Berriasian deposits (S. koeneni to S. damesi Biozone).

Fourth composite depositional sequence include the upper Berriasian (S. damesi Biozone), while the fifth composite depositional sequence include upper Berriasian to lower Valanginian deposits (S. damesi to Olcostephanus (O.) athertoni Biozones), and culminate with the progradation of the shallower oysters-dominated deposits of the Chachao Formation and/or basinal facies of the Agrio Formation.

No evidence of an intravalanginian unconformity was found in the studied area within the Valanginian interval of the Vaca Muerta Forma-tion, which favors an interpretation for its presence in Neuquén province, as a tectonically controlled unconformity.

Fluctuations in organic matter content within the Vaca Muerta Formation suggest their relationship with composite depositional sequences - with the highest values being associated with transgres-sive system tracts.

\section{Acknowledgments}

We are especially grateful to Dr. Susana Damborenea (Universidad Nacional de La Plata y Museo, Argentina) for bivalve identification, and Dr. Miguel Manceñido (Universidad Nacional de La Plata y Museo, Argentina) for brachiopod identification. We thank Dr. Beatriz Bádenas and Dr. Toni Simo for their comments and suggestions that improved significantly the manuscript. This research is part of the Ph.D. thesis of the first author, and has been done under the framework of the UBACyT X-801 (Universidad de Buenos Aires) and PIP 0546 (CONICET) projects. This is the contribution R-117 of the Instituto de Estudios Andinos "Don Pablo Groeber".

\section{References}

Aguirre-Urreta, B., Lazo, D.G., Griffin, M., Vennari, V.V., Parras, A.M., Cataldo, C., Garberoglio, R., Luci, L., 2011. Megainvertebrados del Cretácico y su importancia bioestratigráfica. In: Leanza, H.A., Arregui, C., Carbone, O., Danieli, J.C., Vallés, J.M.(Eds.), Geología y Recursos Naturales de la Provincia del Neuquén, Neuquén, pp. 465-488.

Álvaro, J.J., Clausen, S., 2006. Microbial crusts as indicators of stratigraphic diastems in the Cambrian Brèche à Micmacca, Atlas Mountains of Morocco. Sedimentary Geology $185,255-265$.

Armella, C., Cabaleri, N., Leanza, H.A., 2007. Tidally dominated, rimmed-shelf facies of the Picún Leufú Formation (Jurassic/Cretaceous boundary) in southwest Gondwana, Neuquén Basin, Argentina. Cretaceous Research 28, 961-979.

Bádenas, B., Aurell, M., 2001. Proximal-distal facies relationships and sedimentary processes in a storm dominated carbonate ramp (Kimmeridgian, northwest of the Iberian Range, Spain). Sedimentary Geology 139, 319-340.

Bádenas, B., Aurell, M., Gröcke, D.R., 2005. Facies analysis and correlation of high-order sequences in middle-outer ramp successions: variations in exported carbonate on basin-wide $\delta^{13} \mathrm{C}_{\text {carb }}$ (Kimmeridgian, NE Spain). Sedimentology 52, 1253-1275.

Ballent, S.C., Ronchi, D.I., Angelozzi, G.N., 2004. Microfósiles calcáreos tithonianos (Jurásico superior) en el sector oriental de la cuenca Neuquina, Argentina. Ameghiniana 41, $13-24$.

Ballent, S., Concheyro, A., Náñez, C., Pujana, I., Lescano, M., Carignano, A.P., Caramés, A., Angelozzi, G., Ronchi, D., 2011. Microfósiles mesozoicos y cenozoicos. In: Leanza, H.A., Arregui, C., Carbone, O., Daniela, J.C., Vallés, J.M. (Eds.), Relatorio XVIII Congreso Geológico Argentino. Geología y Recursos Naturales de la Provincia del Neuquén, Neuquén, pp. 489-528.

Bown, P., Concheyro, A., 2004. Lower Cretaceous calcareous nannoplankton from the Neuquén Basin, Argentina. Marine Micropaleontology 52, 51-84.

Boyer, C., Clark, B., Jochen, V., Lewis, R., Miller, C.K., 2011. Shale gas: a global resource. Oilfield Review 23, 28-39.

Burchette, T.P., Wright, V.P., 1992. Carbonate ramp depositional systems. Sedimentary Geology 79, 3-57.

Carozzi, A.V., Bercowski, F., Rodriguez, M., Sanchez, M., Vonesch, T., 1981. Estudio de microfacies de la Formación Chachao (Valanginiano), Provincia de Mendoza. Actas 8 Congreso Geológico Argentino, 2, pp. 545-565.

Carozzi, A.V., Orchuela, I.A., Rodriguez Schelotto, M.L., 1993. Depositional models of the Lower Cretaceous Quintuco-Loma Montosa Formation, Neuquén Basin, Argentina. Journal of Petroleum Geology 16, 421-450.

Charrier, R., 1985. Estratigrafía, evolución tectónica y significado de las discordancias de los Andes chilenos entre $32^{\circ} \mathrm{S}$ y $36^{\circ} \mathrm{S}$ durante el Mesozoico y Cenozoico. In: Frutos, J., Oyarzún, R., Pincheira, M. (Eds.), Geologia y Recursos Minerales de Chile. Universidad de Concepción, Concepción, pp. 101-133.

Cruz, C., Boll, A., Gómez Omil, R., Martínez, E., Arregui, C., Gulisano, C., Laffitte, G., Villar, H.J., 2002. Hábitat de hidrocarburos y sistemas de carga Los Molles y Vaca Muerta en el sector central de la Cuenca Neuquina, Argentina. V Congreso de Exploración y Desarrollo de HidrocarburosIAPG, CD-ROM, Mar del Plata.

Embry, A.F., Johannessen, E.P., 1992. T-R sequence stratigraphy, facies analysis and reservoir distribution in the uppermost Triassic-Lower Jurassic succession, western Sverdrup Basin, Arctic Canada. In: Vorren, T.O., Bergsager, E., Dahl-Stamnes, O.A. Holter, E., Johansen, B., Lie, E., Lund, T.B. (Eds.), Arctic Geology and Petroleum Poten-tial. Norwegian Petroleum Society, Special Publication, 2, pp. 121-146.

Emery, D., Myers, K.J., 1996. Sequence Stratigraphy. Blackwell, Oxford (297 pp.). Fernández

Carmona, J., Riccardi, A.C., 1998. Primer hallazgo de Chitinoidella Doben en el Tithoniano de la Argentina. 10 Congreso Latinoamericano de Geología y 6 Congreso Nacional de Geología Económica, Actas, 1, p. 292.

Fernández Carmona, J., Riccardi, A.C., 1999. Primer reporte de Calpionélidos calcáreos del Cretácico inferior -Berriasiano de la Provincia del Tethys en la República Argentina: Conexión Tethys-Pacífico. Boletim do Simposio sobre o Cretaceo do Brasil, pp. 465-466.

Flügel, E., 2004. Microfacies of Carbonate Rocks. Análisis, Interpretation and AplicationSpringer-Verlag, Berlin-Heidelberg (976 pp.).

Giambiagi, L.B., Álvarez, P., Godoy, E., Ramos, V.A., 2003. The control of pre-existing extensional structures on the evolution of the southern sector of the Aconcagua fold and thrust belt, southern Andes. Tectonophysics 369, 1-19.

Giambiagi, L., Bechis, F., Lanés, S., Tunik, M., García, V., Suriano, J., Mescua, J., 2008. Formación y evolución triásico-jurásica del Depocentro Atuel, Cuenca Neuquina, provincia de Mendoza. Revista de la Asociación Geológica Argentina 63, 520-533.

Giusiano, A., Alonso, J., Chebli, G., Ibáñez, G., 2011. Gas no convencional en la cuenca Neuquina. El shale gas en la provincia del Neuquén. Informe de la Subsecretaría de Hidrocarburos, Energía y Minería, Gobierno de la Provincia del Neuquén (54 pp.). Graham,

J.J., 2012. Controls on the Temporal and Spatial Distribution of Organic Matter in Siliciclastic Mudstones: Implications for Source Rock Development in Shale Gas Plays. PhD. Thesis University of Leicester, Leicester (232 pp.).

Groeber, P., 1946. Observaciones geológicas a lo largo del meridiano 70 Hoja Chos Malal Revista de la Asociación Geológica Argentina 1, 178-208.

Groeber, P., 1953. Ándico. In: Groeber, P., Stipanicic, P.N., Mingramm, A. (Eds.), Geografía de la República Argentina. Sociedad Argentina de Estudios Geográficos GAEA, 2, pp. 349351 . 
Gulisano, C.A., Gutiérrez Pleimling, A.R., Digregorio, R.E., 1984. Análisis estratigráfico del intervalo Tithoniano-Valanginiano (Formaciones Vaca Muerta, Quintuco y Mulichinco) en el suroeste de la provincia de Neuquén. 9 Congreso Geológico Argentino, Actas, 1, pp. 221235.

Handford, C.R., Loucks, R.G., 1993. Carbonate depositional sequences and systems tracts responses of carbonate platforms to relative sea-level changes. In: Loucks, R.G., Sarg, J.F. (Eds.), Carbonate Sequence Stratigraphy. AAPG Memoir, 57, pp. 3-42.

Haq, B.U., Hardenbol, J., Vail, P.R., 1987. Chronology of fluctuating sea level since the Triassic. Science 235, 1156-1167.

Haq, B.U., Hardenbol, J., Vail, P.R., 1988. Mesozoic and Cenozoic chronostratigraphy and cycles of sea-level change. In: Wilgus, C.K., Hastings, B.S., Ross, C.A., Posamentier, H., Van Wagoner, J., Kendall., C.G.S.C. (Eds.), Sea Level Changes - An Integrated Approach, SEPM Special Publication, 42, pp. 71-108.

Hardie, L.A., 1986. Stratigraphic models for carbonate tidal-flat deposition. In: Hardie, L.A., Shinn, E.A. (Eds.), Carbonate Depositional Environments. Colorado School of Mines 3 , Tidal Flats, pp. 59-74

Howell, J.A., Schwarz, E., Spalletti, L.A., 2005. The Neuquén Basin: an overview. In: Veiga, G.D., Spalletti, L.A., Howell, J.A., Schwarz, E. (Eds.), The Neuquén Basin, Argentina: A Case Study in Sequence Stratigraphy and Basin Dynamics. Geological Society of London, Special Publication, 252, pp. 1-13.

Kerans, Ch., Tinker, S., 1997. Sequence stratigraphy and characterization of carbonate reservoirs. SEPM Short, Course Notes, 40 1-128.

Kershaw, S., 1994. Classification and geological significance of biostromes. Facies 31, $81-92$.

Kiessling, W., 1996. Facies characterization of Mid-Mesozoic deep-water sediments by quantitative analysis of siliceous microfaunas. Facies 35, 237-274.

Kietzmann, D.A., 2011. Análisis sedimentológico y cicloestratigráfico de una sucesión orbitalmente controlada (Formación Vaca Muerta) en el límite Jurásico-Cretácico de la cuenca Neuquina surmendocina. PhD. Thesis Universidad de Buenos Aires, Buenos Aires (584 pp.).

Kietzmann, D.A., Palma, R.M., 2009a. Tafofacies y biofacies de Formación Vaca Muerta en el sector surmendocino de la Cuenca Neuquina: implicancias paleoecológicas, sedimentológicas y estratigráficas. Ameghiniana 46, 321-343.

Kietzmann, D.A., Palma, R.M., 2009b. Microcrinoideos saccocómidos en el Tithoniano de la Cuenca Neuquina. ¿Una presencia inesperada fuera de la región del Tethys? Ameghiniana 46, 695-700.

Kietzmann, D.A., Palma, R.M., 2010a. Primer registro de microcoprolitos de crustáceos de la Cuenca Neuquina: el icnogenero Palaxius en el Tithoniano de la Formación Vaca Muerta. Ameghiniana 47, 257-261.

Kietzmann, D.A., Palma, R.M., 2010b. New crustacean microcoprolites from the Lowe Cretaceous (middle Berriasian-lower Valanginian) of the Neuquén Basin, southern Mendoza, Argentina. Journal of South American Earth Sciences 30, 58-64.

Kietzmann, D.A., Palma, R.M., 2011. Las tempestitas peloidales de la Formación Vaca Muerta (Tithoniano-Valanginiano) en el sector surmendocino de la Cuenca Neuquina, Argentina. Latin American Journal of Sedimentology and Basin Analysis 18, 121-149.

Kietzmann, D.A., Vennari, V.V., 2013. Sedimentología y estratigrafía de la Formación Vaca Muerta (Tithoniano-Berriasiano) en el área del cerro Domuyo, norte de Neuquén, Argentina. Andean Geology 40, 41-65.

Kietzmann, D.A., Palma, R.M., Bressan, G.S., 2008. Facies y microfacies de la rampa tithoniana-berriasiana de la Cuenca Neuquina (Formación Vaca Muerta) en la sección del arroyo Loncoche-Malargüe, provincia de Mendoza. Revista de la Asociación Geológica Argentina 63, 696-713.

Kietzmann, D.A., Palma, R.M., Ferré, B., 2010a. Interpretation of "Saccocoma microfacies" and their significance in the Tithonian of the Neuquén Basin, Vaca Muerta Formation, Mendoza, Argentina. IV Simposio Argentino del Jurásico y sus Límites, Bahía Blanca, p. 31

Kietzmann, D.A., Blau, J., Fernández, D.E., Palma, R.M., 2010b. Crustacean microcoprolites from the Upper Jurassic-Lower Cretaceous of the Neuquén Basin, Argentina: systematics and biostratigraphic implications. Acta Palaeontologica Polonica 55, 277-284.

Kietzmann, D.A., Martín-Chivelet, J., Palma, R.M., López-Gómez, J., Lescano, M., Concheyro, A., 2011a. Evidence of precessional and eccentricity orbital cycles in a Tithonian source rock: the mid-outer carbonate ramp of the Vaca Muerta Formation, Northern Neuquén Basin, Argentina. AAPG Bulletin 95, 1459-1474.

Kietzmann, D.A., Blau, J., Riccardi, A.C., Palma, R.M., 2011b. An interesting finding of chitinoidellids (Clapionellidea Bonet) in the Jurassic-Cretaceous boundary of the Neuquén Basin. XVIII Congreso Geológico Argentino, pp. 1480-1481.

Leanza, H.A., 1973. Estudio sobre los cambios faciales de los estratos limítrofes JurásicoCretácicos entre Loncopué y Picun Leufú, Provincia del Neuquén, República Argentina. Revista de la Asociación Geológica Argentina 28, 97-132.

Leanza, H.A., Marchese, H.G., Riggi, J.C., 1977. Estratigrafía del Grupo Mendoza con especial referencia a la Formación Vaca Muerta entre los Paralelos $35^{\circ}$ y $40^{\circ} 1 . s$. Cuenca Neuquina-Mendocina. Revista de la Asociación Geológica Argentina 32, 190-208. Leanza, H.A., Hugo, C.A., Repol, D., Salvarredy Aranguren, M., 2003. El Miembro Huncal (Berriasiano inferior): un episodio turbidítico en la Formación Vaca Muerta, Cuenca Neuquina, Argentina. Revista de la Asociación Geológica Argentina 58, 248-254.

Leanza, H.A., Sattler, F., Martinez, R., Carbone, O., 2011. La Formación Vaca Muerta y Equivalentes (Jurásico Tardío-Cretácico Temprano) en la Cuenca. Neuquina. In: Leanza, H.A., Arregui, C., Carbone, O., Daniela, J.C., Vallés, J.M. (Eds.), Geología y Recursos Naturales de la Provincia del Neuquén, Neuquén, pp. 113-129.

Legarreta, L., Gulisano, C.A., 1989. Análisis estratigráfico secuencial de la Cuenca Neuquina (Triásico superior-Terciario inferior, Argentina). In: Chebli, G., Spalletti, L.A. (Eds.), Cuencas Sedimentarias Argentinas. Universidad Nacional de Tucumán, Serie Correlación Geológica, 6, pp. 221-243.

Legarreta, L., Kozlowski, E., 1981. Estratigrafía y sedimentología de la Formación Chachao, provincia Mendoza. $8^{\circ}$ Congreso Geológico Argentino, 2, pp. 521-543.
Legarreta, L., Uliana, M.A., 1991. Jurassic-Cretaceous marine oscillations and geometry of back-arc basin, Central Argentina Andes. In: McDonald, D.I.M. (Ed.), Sea Level Changes at Active Plate Margins: Process and Product. International Association of Sedimentologists, Special Publiocation, 12, pp. 429-450.

Legarreta, L., Uliana, M.A., 1996. The Jurassic succession in west central Argentina: stratal patterns, sequences, and paleogeographic evolution. Palaeogeography, Palaeoclimatology, Palaeoecology 120, 303-330.

Legarreta, L., Kozlowski, E., Boll, A., 1981. Esquema estratigráfico y distribución de facies del Grupo Mendoza en el ámbito surmendocino de la cuenca neuquina. $8^{\circ}$ Congreso Geológico Argentino, Actas, 3, pp. 389-409.

Legarreta, L., Villar, H.J., Laffitte, G.A., Cruz, C.E., Vergani, G., 2005. Cuenca Neuquina: Balance de masa enfocado a la evaluación del potencial exploratorio de los distritos productivos y de las zonas no productivas. VI Congreso de Exploración y Desarrollo de Hidrocarburos, Actas, pp. 233-250.

Lindsay, J.F., Kennard, J.M., Southgate, P.N., 1993. Application of sequence stratigraphy in an intracratonic setting, Amadeus basin, central Australia. In: Posamentier, H.W., Summerhayes, C.P., Haq, B.U., Allen, G.P. (Eds.), Sequence Stratigraphy and Facies Associations. International Association of Sedimentologists, Special Publication, 18, pp. 605-631.

Loucks, R.G., Reed, R.M., Ruppel, S.C., Hammes, U., 2012. Spectrum of pore types and networks in mudrocks and a descriptive classification for matrix-related mudrock pores. AAPG Bulletin 96, 1071-1098.

MacEachern, J.A., Kerrie, L.B., Pemberton, S.G., Gingras, M.K., 2008. The ichnofacies paradigm: high-resolution paleoenvironmental interpretation of the rock record. In: MacEachern, J.A., Bann, K.L., Gingras, M.K., Pemberton, S.G. (Eds.), Applied Ichnology. SEPM Short course notes, pp. 27-64.

Machalski, M., 1989. Oyster life positions and shell beds from the Upper Jurassic of Poland Acta Palaeontologica Polonica 43, 609-634.

Manceda, R., Figueroa, D., 1993. La inversión del rift mesozoico de la faja fallada y plegada de Malargüe. Provincia de Mendoza. 12 Congreso Geológico Argentino y 2 Congreso de Exploración de Hidrocarburos, Actas, 3, pp. 219-232.

Marchese, H.G., 1971. Litoestratigrafia y variaciones litofaciales se las sedimentitas mesozoicas de la Cuenca Neuquina, Prov. de Neuquén, Rep. Argentina. Revista de la Asociación Geológica Argentina 36, 343-410

Maretto, H., Pángaro, F., 2005. Edad de formación de algunas de las grandes estructuras del engolfamiento de la Cuenca Neuquina: Actividad tectónica durante la depositación de la Fm. Quintuco. $6^{\circ}$ Congreso de Exploración y Desarrollo de Hidrocarburos, Actas CD-Room.

Martín-Chivelet, J., Palma, R.M., López-Gómez, J., Kietzmann, D.A., 2011. Earthquakeinduced soft-deformation structures in Upper Jurassic open-marine microbialites (Neuquén Basin, Argentina). Sedimentary Geology 235, 2010-2221.

Mata, S.A., Bottjer, D.J., 2009. Development of Lower Triassic wrinkle structures: implications for the search for life on other planets. Astrobiology 9, 895-906.

Mitchum, R.M., Uliana, M.A., 1985. Seismic stratigraphy of carbonate depositional sequences, Upper Jurassic-Lower Cretaceous. In: Berg, R.B., Woolverton, D.G. (Eds.), Neuquén Basin, Argentina. Seismic Stratigraphy: An Integrated Approach to Hydro-carbon Exploration. AAPG Memoir, 39, pp. 255-274.

Mohseni, H., Al-Aasm, I.S., 2004. Tempestite deposits on a storm-influenced carbonate ramp: an example from the Pabdeh Formation (Paleogene), Zagros Basin, SW Iran. Journal of Petroleum Geology 27, 163-178

Molina, J.M., Ruiz-Ortiz, P.A., Vera, J.A., 1997. Calcareous tempestites in pelagic facies (Jurassic, Betic Cordilleras, Southern Spain). Sedimentary Geology 109, 95-109.

Mombru, C.A., Uliana, M.A., Bercowski, F., 1978. Estratigrafía y sedimentología de las acumulaciones biocarbonáticas del Cretácico Inferior surmendocino. $7^{\circ}$ Congreso Geológico Argentino, Actas, 1, pp. 685-700.

Monaco, P., 1992. Hummocky cross-stratified deposits and turbidites in some sequences of the Umbria-Marche area (central Italy) during the Toarcian. Sedimentary Geology 77, $123-142$

Moreno, K., Pino, M., 2002. Huellas de dinosaurios en la Formación Baños del Flaco (Titoniano-Jurásico Superior), VI Región, Chile: paleoetología y paleoambiente. Revista Geologica de Chile 29, 151-165.

Myrrow, P., 1995. Thalassinoides and the enigma of Early Paleozoic open-framework burrow systems. Palaios 10, 58-74.

Orchuela, I.A., Ploszkiewicz, J.V., Viñes, R., 1981. Reinterpretación estructural de la denominada "Dorsal Neuquina". $8^{\circ}$ Congreso Geológico Argentino, Actas, 3, pp. 81-93.

Palma, R.M., 1996. Analysis of carbonate microfacies in the Chachao Formation (Cretaceous), Barda Blanca-Malargüe, Mendoza Province-Argentina: a cluster analytic approach. Carbonates and Evaporites 11, 182-194.

Palma, R.M., Angeleri, M.P., 1992. Early Cretaceous serpulid limestones: Chachao Formation, Neuquén basin, Argentina. Facies 27, 175-178.

Palma, R.M., Lanés, S., 2001. Shell bed stacking patterns in the Chachao Formation (early Valanginian) in Malargüe Area, Mendoza Province, Neuquén Basin-Argentina. Carbonates and Evaporites 16, 168-180.

Palma, R.M., Meléndez, M.N., Calvo, J.P., Lanés, S., 2000. Abultamiento biodetrítico en la Formación Chachao (Valanginiano): características y evolución ambiental, Malargüe, Mendoza. Revista de la Asociación Geológica Argentina 55, 300-308.

Palma, R.M., Bressan, G.S., Kietzmann, D.A., 2008. Diagenesis of a bioclastic oyster deposit from the Lower Cretaceous (Chachao Formation). Neuquén basin. Mendoza Province, Argentina. Carbonates and Evaporites 23, 39-49.

Passey, Q.R., Bohacs, K.M., Esch, W.L., Klimentidis, R., Sinha, S., 2010. From Oil-Prone Source Rock to Gas-Producing Shale Reservoir - Geologic and Petrophysical Characterization of Unconventional Shale-Gas Reservoirs. CPS/SPE 131350

Pemberton, S.G., MacEachern, J.A., Ranger, M.J., 1992. Ichnology and event stratigraphy: the use of trace fossils in recognizing tempestites. In: Pemberton, S.G. (Ed.), Applications of Ichnology to Petroleum Exploration-A Core Workshop. SEPM, Core Workshop, 17, pp. 15118 . 
Playton, T.E., Janson, X., Kerans, Ch., 2010. Carbonate slopes. In: James, N.P., Darlymple, R.W. (Eds.), Facies Models 4. Geological Association of Canada, Newfoundland, pp. $449-476$.

Pomar, L., Kendall, Ch.G.St.C, 2008. Architecture of carbonate platforms: a response to hydrodynamics and evolving ecology. In: Lukasik, J., Simo, T.J.A. (Eds.), Controls on Carbonate Platform and Reef Development. SEPM Special Publication, 89, pp. 187-216.

Pryor, W.A., 1975. Biogenic sedimentation and alteration of argillaceous sediments in shallow marine environments. GSA Bulletin 86, 1244-1254.

Quattrocchio, M.E., Sarjeant, W.A.S., Volkheimer, W., 1996. Marine and terrestrial Jurassic microfloras of Neuquén Basin (Argentina): Palinological Zonation. In: Riccardi, A.C.(Ed.), Advances in Jurassic Research. Transtec Publications, GeoResearch Forum, 1-2, pp. 167178 .

Ramos, V.A., 2010. The tectonic regime along the Andes: present-day and Mesozoic regimes. Geological Journal 45, 2-25.

Ramos, V.A., Folguera, A., 2005. Tectonic evolution of the Andes of Neuquén: constraints derived from the magmatic arc and Foreland deformation. In: Veiga, G.D., Spalletti, L.A., Howell, J.A., Schwarz, E. (Eds.), The Neuquén Basin, Argentina: A Case Study in Sequence Stratigraphy and Basin Dynamics. Geological Society of London, Special Publication, 252, pp. 15-35.

Riccardi, A.C., 2008. The marine Jurassic of Argentina: a biostratigraphic framework. Episodes 31, 326-335.

Riccardi, A.C., Leanza, H.A., Damborenea, S., Manceñido, M., Ballent, S., Zeiss, A., 2000 Marine Mesozoic biostratigraphy of the Neuquén Basin. 31st Internacional Geological Congress, Río de Janeiro, pp. 103-108.

Riccardi, A.C., Damborenea, S.E., Manceñido, M.O., Leanza, H.A., 2011. Megainvertebrados jurásicos y su importancia geobiológica. In: Leanza, H.A., Arregui, C., Carbone, O. Daniela, J.C., Vallés, J.M. (Eds.), Geología y Recursos Naturales de la Provincia del Neuquén, Neuquén, pp. 441-464.

Sagasti, G., Ballent, S., 2002. Caracterización microfaunística de una transgresión marina: Formación Agrio (Cretácico inferior), Cuenca Neuquina, Argentina. Geobios 35, 721-734. Savrda,

C.E., Bottjer, D.J., 1986. Trace fossil model for reconstruction of paleo-oxygenation in bottom waters. Geology 14, 3-6.

Scasso, R.A., 2001. High-frequency explosive volcanic eruptions in a Late Jurassic volcanic arc: the Ameghino Formation, Antarctica Peninsula. Journal of Sedimentary Research 71, 101-106.

Scasso, R.A., Alonso, S.M., Lanés, S., Villar, H.J., Lippai, H., 2005. Geochemistry and petrology of a Middle Tithonian limestone-marl rhythmite in the Neuquén Basin, Argentina: depositional and burial history. In: Veiga, G.D., Spalletti, L.A., Howell, J.A., Schwarz, E. (Eds.), The Neuquén Basin, Argentina: A Case Study in Sequence Stratig-raphy and Basin Dynamics. Geological Society of London, Special Publication, 252, pp. 207-229.

Schieber, J., 1998. Possible indicators of microbial mat deposits in shales and sandstones. Examples from the Mid-Proterozoic Belt Supergroup, Montana, USA. Sedimentary Geology 120, 105-124.

Schieber, J., 1999. Microbial mats in terrigenous clastic: the challenge of identification in the rock record. Palaios $14,3-12$.

Schieber, J., Southard, J.B., 2009. Bedload transport of mud by floccule ripples — direct observation of ripple migration processes and their implications. Geology 37, 483-486. Schieber,

J., Southard, J.B., Schimmelmann, A., 2010. Lenticular shale fabrics resulting from intermittent erosion of water-rich muds - interpreting the rock record in the light of recent flume experiments. Journal of Sedimentary Research 80, 119-128. Schlager, W.,

2005. Sedimentology and sequence stratigraphy of carbonate rocks. SEPM Concepts in Sedimentology and Paleontology 8, 200.

Seilacher, A., Reif, W.E., Westphal, F., Riding, R., Clarkson, E.N.K., Whittington, H.B., 1985. Sedimentological, ecological and temporal patterns of fossil Lagerstätten. Philosophical Transactions of the Royal Society of London, Series B: Biological Sciences 311, 5-24. Slatt, R.M., O'Brien, N.R., 2011. Pore types in the Barnett and Woodford gas shales: contribution to understanding gas storage and migration pathways in fine-grained rocks. AAPG Bulletin 95, 2017-2030
Spalletti, L.A., Franzese, J.R., Matheos, S.D., Schwarz, E., 2000. Sequence stratigraphy of tidally dominated carbonate-siliciclastic ramp; the Tithonian-Early Berriasian of the Souther Neuquén Basin, Argentina. Geological Society of London, Special Publication 157, 433-446.

Stipanicic, P.N., 1969. El avance en los conocimientos del Jurásico argentino a partir del esquema de Groeber. Revista de la Asociación Geológica Argentina 24, 367-388. Stipanicic, P.N., Rodrigo, F., 1970. El diastrofismo jurásico en Argentina y Chile. IV Jornadas de Geología Argentina, Actas, 2, pp. 353-368.

Taylor, J.D., Glover, E.A., 2006. Functional anatomy, chemosymbiosis and evolution of the Lucinidae. In: Harper, E.M., Taylor, J.D., Crame, J.A. (Eds.), The Evolutionary Biology of the Bivalvia. Geological Society of London, Special Publication, 177, pp 207-225.

Tedesco, L.P., Wanless, H.R., 1991. Generation of sedimentary fabrics and facies by repetitive excavation and storm infilling of burrow networks: Holocene of south Florida and Caicos Platform, B.W.I. Palaios 6, 326-343.

Tucker, M.E., Calvet, F., Hunt, D., 1993. Sequence stratigraphy of carbonate ramps: systems tracts, models and application to the Muschelkalk carbonate platforms of eastern Spain. In Posamentier, H.W., Summerhayes, C.P., Haq, B.U., Allen, G.P. (Eds.), Sequence Stratigraphy and Facies Associations. International Association of Sedimen-tologists, Special Publication, 18, pp. 397-415.

Uliana, M.A., Legarreta, L., 1993. Hydrocarbons habitat in a Triassic-to-Cretaceous Sub-Andean setting: Neuquén Basin, Argentina. Journal of Petroleum Geology $16,397-420$

Uliana, M.A., Dellape, D.A., Pando, G.A., 1977. Análisis estratigráfico y evaluación del potencial petrolífero de las Formaciones Mulichinco, Chachao y Agrio, Cretácico Inferior de las Provincias de Neuquén y Mendoza. Petrotecnia 1-2, 41-46.

Uliana, M.A., Legarreta, L., Laffite, G.A., Villar, H.J., 1999. Estratigrafia y geoquímica de las facies generadoras de hidrocarburos en las cuencas petrolíferas de Argentina. IV Congreso de Exploración y Desarrollo de Hidrocarburos, Actas, 1, pp. 1-61.

Urien, C.M., Zambrano, J.J., 1994. Petroleum systems in the Neuquén Basin, Argentina. In: Magoon, L.B., Dow, W.G. (Eds.), The Petroleum System-From Source to Trap. American Association of Petroleum Geologists, Memoir, 60, pp. 513-534.

Van Wagoner, J.C., Mitchum, R.M., Campion, K.M., Rahmanian, V.D., 1990. Siliciclastic Sequence Stratigraphy in Well Logs, Cores, and Outcrops: Concepts for High-Resolution Correlation of Time and Facies. American Association of Petroleum Geologists, Methods in Exploration Series, 7, pp. 1-55.

Vergani, G.D., Tankard, A.J., Belotti, H.J., Welkink, H.J., 1995. Tectonic evolution and paleogeography of the Neuquén Basin, Argentina. In: Tankard, A.J., Suarez Soruco, R., Welsink, H.J. (Eds.), Petroleum Basins of South America. AAPG Memoir, 62, pp. 383-402.

Villar, H.J., Laffite, G.A., Legarreta, L., 1998. The source Rocks of the Mesozoic Petroleum Systems of Argentina: a comparative overview on their geochemistry, paleoenvironments and hydrocarbon generation patterns. International Congress and Exhibition of the American Association of Petroleum Geologists and the Brazilian Association of Petroleum Geologists, Abstracts, pp. 186-187.

Volkheimer, W., Rauhut, O.W.M., Quattrocchio, M.E., Martinez, M.A., 2008. Jurassic paleoclimates in Argentina, a review. Revista de la Asociación Geológica Argentina $63,549-556$.

Wanless, H.R., 1979. Role of physical sedimentation in carbonate bank growth. AAPG Bulletin 63, 540-547.

Wanless, H.R., Tedesco, L.P., Tyrrell, K.M., 1988. Production of subtidal tubular and surficial tempestites by hurricane Kate, Caicos Platform, British West Indies. Journal of Sedimentary Petrology 58, 739-750.

Warme, J.E., 1967. Graded bedding in the recent sediments of Mugu Lagoon, California. Journal of Sedimentary Petrology 37, 540-547.

Weaver, C., 1931. Paleontology of the Jurassic and Cretaceous of West Central Argentine., 1. Memoir, University of Washington (469 pp.).

Whitham, A.G., 1993. Facies and depositional processes in an Upper to Lower Cretaceous pelagic sedimentary sequence, Antarctica. Sedimentology 40, 331-349. 